NBER WORKING PAPER SERIES

\title{
WHO FEELS THE NUDGE? KNOWLEDGE, SELF-AWARENESS AND RETIREMENT SAVINGS DECISIONS
}

\author{
Anders Anderson \\ David T. Robinson \\ Working Paper 25061 \\ http://www.nber.org/papers/w25061 \\ NATIONAL BUREAU OF ECONOMIC RESEARCH \\ 1050 Massachusetts Avenue \\ Cambridge, MA 02138 \\ September 2018
}

We are grateful to Patrick Bolton, Magnus Dahlquist, Harrison Hong, Yaron Levi, Annamaria Lusardi, Olivia S. Mitchell, Terry Odean, Avi Wohl and seminar participants at the Stockholm School of Economics, Oxford, the University of Georgia, Florida State University, Carnegie Mellon University and the 2018 London School of Economics Winter Conference, the 2018 Cherry Blossom Financial Education Institute conference at the George Washington University, the 2018 EFA and 2019 AFA conference for helpful comments. Yao Fu, Ivika Jäger and Zihao Liu provided excellent research assistance. We are especially grateful to Magnus Dahlquist, José Martinez and Paul Söderlind for sharing their data on coordinated trades. The views expressed herein are those of the authors and do not necessarily reflect the views of the National Bureau of Economic Research.

NBER working papers are circulated for discussion and comment purposes. They have not been peerreviewed or been subject to the review by the NBER Board of Directors that accompanies official NBER publications.

(C) 2018 by Anders Anderson and David T. Robinson. All rights reserved. Short sections of text, not to exceed two paragraphs, may be quoted without explicit permission provided that full credit, including (C) notice, is given to the source. 
Who Feels the Nudge? Knowledge, Self-Awareness and Retirement Savings Decisions Anders Anderson and David T. Robinson

NBER Working Paper No. 25061

September 2018, Revised February 2019

JEL No. G11,G18,G4,G41

\begin{abstract}
$\underline{\text { ABSTRACT }}$
Using a financial literacy survey of Swedish pension investors matched to actual retirement savings decisions, we argue that respondents can be broken into three groups: those who are financially literate, those who mistakenly believe they are financially literate, and those who know that they are not. We examine how these groups respond differently to informational nudges encouraging them to take charge of their own investments. Investors with mistaken beliefs responded to the nudge, and were more likely to work with mass-market advisors who steer them into high-fee funds. They underperform as a result. By comparison, those who either possess financial literacy or else understand that they do not possess financial literacy were less likely to respond to the nudge. They avoided advisors, stayed with the low-cost default fund, and therefore accumulated retirement savings more quickly.
\end{abstract}

\author{
Anders Anderson \\ Stockholm School of Economics \\ Drottninggatan 98 \\ Stockholm, Sweden \\ Anders.Anderson@hhs.se \\ David T. Robinson \\ Fuqua School of Business \\ Duke University \\ 100 Fuqua Drive \\ Durham, NC 27708 \\ and NBER \\ davidr@duke.edu
}




\section{Introduction}

Over the last twenty years, public and private retirement plans around the world have moved away from defined benefit schemes towards defined contribution schemes, placing the onus of retirement planning on individuals and households. As a result, increasing amounts of financial sophistication and engagement are required in order to simply make routine retirement savings decisions. To encourage engagement with long-range financial planning decisions that are otherwise easy to ignore or postpone in the shortrun, a common policy strategy is to use information campaigns to encourage attention and action, in combination with a choice architecture that creates well-structured default options for those who remain disengaged. ${ }^{1}$

But inaction is not the only behavioral bias that affects long-range financial planning decisions. Limited familiarity with financial decisions, limited financial knowledge, and inaccurate self-perceptions also impact long-range financial decision-making. Indeed, as Anderson, Baker, and Robinson (2017) show, many individuals appear to hold mistaken beliefs about their own financial expertise; moreover, these beliefs are more important than their actual knowledge for predicting their level of engagement with savings and retirement decisions. This raises important questions about how nudges interact with other behavioral tendencies.

In this paper, we study this interaction by making use of a kind of natural experiment that exposed some individuals, but not others, to an information campaign encouraging active choice. Our primary focus in on the role of self-awareness, or what Kruger and Dunning (1999) call metacognition-knowing what one does and does not know. Using a detailed behavioral survey of a random sample of Swedish households which we link to administrative and tax records, we group people into three categories based on their responses to questions that gauge domain-relevant financial sophistication: those who are financially knowledgeable (those who know), those who are aware that they are not financially knowledgeable (those who know they don't know), and those who are unaware that they hold mistaken beliefs about their financial knowledge (those who don't know they don't know). The distinction between being knowledgeable, aware of one's own

\footnotetext{
${ }^{1}$ See, for example, Thaler and Sunstein (2008), Beshears et al. (2016), Lusardi and Mitchell (2011) and Hastings, Madrian, and Skimmyhorn (2013).
} 
lack of knowledge, or unaware is critical for understanding how individuals respond.

The natural experiment occurred in the context of the reform of the Swedish pension system. In the late 1990s, the Swedish government began a transition from a fully defined benefit pension system to a mixed system in which a fixed proportion of income was allocated to a defined contribution plan to supplement the standard retirement plan. Starting in 2000, all members of the Swedish labor force were allowed to allocate this defined contribution balance across a large number of appropriately registered mutual funds. Investors who did not make a choice were allocated to a low-fee, well diversified, global index fund. The pension system offers hundreds of equity, bond, target-date and mixed funds; these vary significantly in terms of both fees and historical performance.

Importantly, the initial cohort of pension savers was exposed to what Cronqvist, Thaler, and $\mathrm{Yu}(2018)$ call the "Do it Yourself Nudge": in order to promote maximum engagement in the new system, the Swedish government initially embarked on a large-scale information campaign designed to encourage citizens to make an active portfolio choice in this new plan. This nudge was then dropped in the wake of the tech crash that occurred in the early 2000s. Effectively, this means that one group of individuals was exposed to the government's nudge while other groups were not.

Certain aspects of this choice architecture allow us to draw much sharper welfare conclusions than would otherwise be possible. In particular, the level of pension savings in the program is externally mandated, and not a choice of the individual retirement saver. As Campbell (2006) points out, because it is difficult to observe the financial constraints that individual households face, it is challenging to establish whether households are behaving sub-optimally when they save more or less than they might otherwise. Because the nudges in our study do not affect the participation margin, but instead how a fixed proportion is allocated, the welfare conclusions from our analysis are much more stark than in most previous work.

As Cronqvist, Thaler, and Yu (2018) have also shown, this nudge worked: the opt-out rate is much higher in the nudged cohort than in later cohorts. Our contribution lies in understanding which types of individuals responded to the nudge. This in turn allows us to speak to the underlying mechanisms responsible for how the nudge moved people into action. 
We find that in the nudged cohort, unaware investors were much more likely to act on the nudge than knowledgeable investors. Moreover, investors who are unaware of their lack of knowledge are more likely to choose high-fee funds when they opt out of the default fund. After the nudge was removed, unaware investors are no more likely than knowledgeable investors to opt-out, and the group with meta-cognition-those who knew they did not know-are the ones most likely to remain in the default fund. This group is also much larger in number after the nudge is removed, which suggests that psychologically the nudge works by encouraging people to form an opinion on an issue about which they are uncertain, which in turn then leads them to act. Well-structured choice defaults protect against costly inaction, but not against an action rooted in mistaken beliefs.

After the government stopped encouraging investors to make active retirement planning choices, a class of retirement savings tele-marketing firms emerged offering to assist people in directing their pension portfolios. This very fact illustrates a critical factor in pension program design, which is that choice architecture does not operate in a vacuum: instead it incites competitive responses from market participants. In this context, mass-market retirement planning tele-marketers operated by pooling individual retirement portfolios into a common portfolio and trading that portfolio in a coordinated fashion. Individuals paid these retirement advisors a direct management fee for this service on top of the fees already charged by the mutual funds themselves. Many of these telemarketing advisory firms applied aggressive sales methods and engaged in unscrupulous business practices; as complaints increased, the government in 2011 dramatically constrained their ability to electronically coordinate retirement trading activity. Larger firms responded by establishing their own fund-of-funds, and directing their clients into these products.

By linking our survey and administrative data to data provided by Dahlquist, Martinez, and Söderlind (2017), we can also explore the role that these firms have played in shaping the results described above. The nudged group was much more likely to respond to the tele-marketing than later, non-nudged cohorts. This fact further supports the idea that the informational nudge works by urging people to form an opinion about an issue about which they may be unfamiliar; presumably one reason uptake was higher in the 
nudged cohort is because this group had a heightened sense of the importance of making a decision and was therefore more open to the advice being marketed.

One reason why unaware investors select into higher-fee funds when they opt out is that they are much more likely to sign up with advisors. Those who delegate retirement planning to advisers pay higher fees and earn lower Sharpe-ratios. This is not just an opt-out effect: the fees associated with advisers are higher, on average, than those faced by individuals who opt out of the default pension choice without going through advisers. The economic magnitude of this difference is large. Individuals who use advisors pay average mutual fund fees that are nearly four times those of the default fund; the difference between the median advisor-led fund and the median non-default fund is roughly the same order of magnitude as the fees on the default fund itself. The fees associated with advisor recommendations are roughly 25 percent greater than those faced by individuals who opt out of the default without the assistance of an advisor.

In sum, the do-it-yourself nudge contained two important hidden costs: one was that it encouraged people to act without necessarily equipping them with the relevant knowledge, skills and information to act in their own best interest; a second is that it drove them to take up low-quality advisory services that generated underperformance. These costs were disproportionately borne by individuals who lacked the self-awareness to appreciate the fact that they did not possess the relevant domain-specific knowledge in order to make a well informed choice.

This paper contributes to several strands of research. One is the literature that illustrates the power of nudges to work in a variety of contexts. The closest are Cronqvist, Thaler, and Yu (2018), which studies the Swedish context directly, as well as papers examining retirement and savings decisions (Madrian and Shea (2001); Choi et al. (2004) and Choi et al. (2006); Beshears et al. (2006)) or enrollment in savings plans more generally (Carrol et al. (2009); Beshears et al. (2015)). Ours is the first, however, to examine how variation in average responses to choice architecture is driven by financial literacy and other behavioral factors. ${ }^{2}$ We also add to a broad body of work linking financial literacy to retirement security by augmenting general financial literacy measures with measures of specific knowledge. Finally, our work adds to the literature that explores conflicts of

\footnotetext{
${ }^{2}$ See Beshears et al. (2015) on work linking income to response variation.
} 
interests and the role of advisors in retail financial markets. This literature is too vast to summarize here; see Burke et al (2015) for a comprehensive review.

The remainder of the paper is structured as follows. We begin in Section 2 with a brief description of the institutional setting. In Section 3, we describe the data. Section 4 relates the domain-specific measure of financial sophistication that we use to broader measures of financial literacy and develops our measure of metacognition. Section 5 presents results connecting financial literacy to opting out choices, the resulting fees, and the reliance on advisors. Section 6 studies the performance implications of these decisions. Section 7 concludes.

\section{The Institutional Setting}

\subsection{Historical Background}

In June of 1994, the Swedish Parliament passed legislation that transformed the public pension system from one based on defined benefit to one based on defined contribution. ${ }^{3}$ The exact details of the transition are complicated and are discussed at length in Palme, Sunden, and Söderlind (2007) and Palmer (1995). Our purpose here is to highlight the key features as they pertain to our analysis. Prior to 1994, the system was a flat-rate universal benefit system augmented by an earnings-related supplement. The period between 1994 and 1999 allowed for the accumulation of two types of accounts. One is a notional defined contribution plan linked to an income index and funded on a pay-as-you-go basis based on a contribution rate of $16 \%$ of (capped) labor incomes. ${ }^{4}$ An additional $2.5 \%$ of labor income was credited to a fully funded individual account managed by the pension authority, similar to a 401(k) plan in the United States, but part of the state pension, rather than an occupational pension. Starting from 2000, individuals were allowed to control how this account was invested by allocating this portion of their account across as many as five different funds. In 2000, there were 456 funds available, a number that has grown

\footnotetext{
${ }^{3}$ The 1990s were a period of tremendous economic change and upheaval in Sweden more generally. In 1990 and 1991, the Swedish tax system was completely overhauled, reducing tax rates and broadening the base of taxpayers (Agell, Englund, and Södersten (1995), "The Swedish Tax Reform: An Introduction" Swedish Economic Policy Review 2, 219-228). In the fall of 1992, the country experienced a banking crisis following a collapse in real estate prices.

${ }^{4}$ There is also a mean-tested benefit that provides a minimum pension.
} 
to 855 at the end of 2015.

The SPA maintains the fund platform and administrates the deposits and redemptions on behalf of the investors. Individual account information is available through their webpage, but also sent out by letter once a year (known in Sweden as the "the orange envelope"), which provides a summary of performance as well as a long term projection of the pension outcome. Funds available on the platform are required to follow the European UCITS Directive which puts some restrictions on minimum diversification and transparency, but there are no other specific prerequisites for allowing or preventing fund companies to enter. Funds are however required to follow a discount schedule, which is based on the size of the total SPA investment on the fund family level. Discounts are paid back at the individual account level, and therefore vary across funds. The PPA also charges a small fee from each account to cover its costs. We provide a detailed description of the fees in Section 3.

\subsection{The Informational Nudge and the Rise of Mass-Market Advisors}

The introduction of the system was accompanied by an extensive information campaign encouraging workers to make an active choice. A booklet containing assessments of risk, fees and past performance for 456 funds managed by 72 fund companies was sent out to around 4 million people affected by the change, encouraging them to allocate their savings between one to five funds. As argued in Cronqvist and Thaler (2004), policymakers in Sweden clearly nudged their citizens to make an active choice over falling into the default fund. In 2000, the initial year, almost two-thirds made an active choice, but enthusiasm for active choice did not last long. Of those entering the system in 2001, only $18 \%$ made an active choice at the point they entered, and 29\% of this cohort had made a choice six years later in 2007. Of those entering 2007, less than $2 \%$ made an active choice initially, and by 2013 , only $20 \%$ had done so. ${ }^{5}$

The fact that a low fraction of individuals made an initial choice, but a much larger share later opted out of the default fund, is widely attributed to the emergence of retirement advisors working aggressively with telemarketing towards very broad layers of the population. The advisor would typically offer to rebalance the individual's pension port-

\footnotetext{
${ }^{5}$ Data obtained from the Swedish government committee report SOU 2016:61.
} 
folio in exchange for a fee, usually between SEK 500 to 1,000 per year (around USD 100). ${ }^{6}$ To facilitate this, the individual would share the PIN-code to her account at the SPA with the advisory firm, allowing the advisor to make automated changes across a large number of accounts. The SPA reports that the number of fund changes grew from around a half a million in 2004 to four and a half million in 2009. As this segment of the market grew, the government received increasing numbers of complaints against advisors and their sales methods, as well as raising a discussion about the added value they provide.

In 2011, the government instructed the SPA to redesign its web interface in order to prohibit robots from making mass changes on behalf of individual accounts. The trading impact was immediate, as from December 2011, the number of transactions fell by $75 \%$. Many of the larger advisor firms responded by forming their own fund-of-funds to which they steered customers in order to retain the mandate to manage their pension savings. Though most advisors stopped charging the direct, fixed yearly advisory fee after the change, the fund-of-fund structure they offered as an alternative had higher than average fees.

\section{Data}

Our data are assembled from the Swedish Pensions Agency, which provides mutual fund returns data; data from Dahlquist, Martinez, and Söderlind (2017), which allowed us to determine the role that advisors play in the retirement planning decision; and data from Statistics Sweden, which conducted a financial literacy survey on our behalf and merged the data with Swedish tax records and pension contribution data. We next describe each of these in detail.

\subsection{Swedish Pensions Agency}

Our data include all fund returns and fees from the SPA since the program's inception in 2000. Panel A of Table I reports pension fund investments and fees across eight fund types, as classified by the SPA. There are 789 and 155 holdings in the default equity and

\footnotetext{
${ }^{6}$ Even if this fee is relatively low in nominal terms, it commonly represents $1 \%$ to $2 \%$ of individuals' accounts according to the SPA. The relatively small accounts are explained by the implied build-up through contributions over peoples' working life.
} 
bond fund, respectively, where individuals in the bond fund also have holdings in the equity fund. The default funds are managed by the government-controlled AP 7 fund and takes the form of a target date fund. ${ }^{7}$ Young individuals who do not actively choose a fund are automatically enrolled in the equity fund. After the age of 56, allocations to the bond fund are made progressively in five steps up to the age 75 , when the default portfolio consists of two-third bonds.

-Table I here-

Around a quarter of the value of all pension assets are invested in the default fund, and around half in equity funds, which is also by far the biggest category measured by the number of different funds. Mixed and Target date funds together constitute around a quarter of fund investments, and Bond funds have a negligible share of the overall value of investments.

The fees we report are net of discounts negotiated on behalf of investors by the authority, but excludes the service fee charged to all accounts by the SPA. ${ }^{8}$ The discounts are paid back annually to investors and are substantial. According to the SPA, as much as two-thirds of total management fees are distributed back to investors every year. There is a cap on the net fees since 2015. The maximum fee after discounts for equity funds is 0.89 percent, and for mixed and target date funds it is 0.62 . The maximum fee for bond funds was set to 0.42 percent.

Fees are reported in the last three columns of Panel A of Table I and points out the low management fees for the default funds. The AP 7 equity and bond fund charges 12 and 5 basis points (bps) annually. The highest fees are found in the equity fund category, where the median fund in our sample charges $51 \mathrm{bps}$, and the upper quartile $70 \mathrm{bps}$. The median fee for a Mixed fund is 38 bps, and for a Bond fund it is 19 bps - all of them well above the default alternatives.

\footnotetext{
${ }^{7}$ Since May 2010, the equity default fund has a mandate to gear its equity exposure up to 1.5. Although the gearing changes over time, it has been relatively stable around 1.2 to 1.3 during the sample period. Because the stock market has performed well during most of this time, the default fund has outperformed most other funds.

${ }^{8}$ The service fee is determined annually to cover the administrative costs of the system. In 2015, it was 13 basis points with a cap of SEK 120 for each pension account.
} 


\subsection{Advisor-led trades}

Panel C of Table I reports frequencies of advisor-led trades. We flag trades in our data as advisor-led by cross-checking trades against data from Dahlquist, Martinez, and Söderlind (2017). Their dataset includes a large random sample of 480,000 people of all 6 million members of the Swedish pension system making over 10 million choices, from which they identify coordinated trades as trades defined by the number of identical portfolio choices made the same day. We use a similar methodology to determine coordinated trades. Because we can only observe choices, and not the client-customer relation itself, it is an empirical matter to determine a reasonable cut-off for the number of coordinated trades in order to attribute them to advisors. We use three break-points in this paper to classify investor-initiated trades: the same 1,000 identical trades benchmark used by Dahlquist, Martinez, and Söderlind (2017), the 25th percentile of coordination size (3,076 identical trades occurring at the same point in time) and the 50th percentile of coordination size (12,535 trades). For each classification in the larger data set, we then match the coordinated portfolio and date onto our smaller set of investors and flag them as coordinated. The first two classifications are relatively insensitive to the number investors classified as having advisors. There are 353 investors in our data who made a trade that was coordinated with at least 1,000 other individuals, and 330 investors using the 25th percentile breakpoint. Using the upper half of the distribution, we classify 220 individuals, or almost $9 \%$ of the sample, as having enrolled with an advisor. The classification of advisor-led activity is therefore quite insensitive to different assumptions about the activity at the lower end of the distribution, but may act too restrictive in the upper half in order to capture all of them.

Because our varying thresholds for defining investor-led trades are based on the number of simultaneous, identical trades, this threshold classification also naturally sorts individuals according to the size of the advisory firm with which they are affiliated: a greater degree of coordination implies a larger market share for the advisor firm. This is an important source of variation for us, since many of the larger, mass-market advisory firms changed business model after 2011 to steer customers towards their own fund-of-funds as it became impossible to coordinate large numbers of trades simultaneously through a single electronic trade. Panel C of Table I reveal that our classification captures 59\% of 
all trades in our sample defined as 1,000 simultaneously changes at one time; this falls to $34 \%$ if we set the threshold at the median.

\subsection{Measuring Financial Literacy}

Our second source of data is a web-based survey designed to measure actual and perceived financial literacy, both at a broad level as well as it pertains to the specifics of mutual fund investing.

\subsubsection{Survey implementation}

We construct a short web survey with 21 questions including a version of the standard Big 5 financial literacy questions, which appears in the National Financial Capability Studies (NFCS). ${ }^{9}$ Invitations to take the survey were sent by regular mail by Statistics Sweden in January 2016 to 12,000 people in the ages 18 to 65 . Sampling from this age range is designed to match normal working ages in Sweden. There are approximately 5.9 million Swedes in this age group, and we are able to benchmark the demographics of participants in our study against that of the overall population. We received 1,564 responses after the first invite, and a total of 2,854 responses after two reminders sent out in February and early March, which translates into a total response rate of almost 24\%. After deleting incomplete responses and matching with socio-demographics and pension fund choices we are left with 2,502 complete survey observations.

We match the survey responses to fund holdings obtained by the pension authority. Panel B of Table I shows that the number of investors in the default fund in the year of 2000 was $24 \%$, or 422 out of 1,768 individuals. The majority, or two-thirds of those who entered after 2000 did not make an active choice, and 73 people opted out of the default fund by 2015. At the end of 2015, there are 854 individuals in the default fund in our sample, which constitutes $34 \%$ of the 2,502 survey respondents. We find that $18 \%$ of investors in sample only traded once, meaning that they chose to leave the default fund, but never made any further changes to the portfolio.

\footnotetext{
${ }^{9}$ See Lusardi and Mitchell (2014) for an overview.
} 


\subsubsection{Survey design}

Our version of the Big 5 financial literacy questions and responses are displayed in the Appendix in Table A.1. Because standard residential mortgages in Sweden typically do not exist in the same form as in the U.S., we opt instead to include a question related to savings and compounding, known as the "72" rule of thumb. Questions of this sort have previously appeared in the work of Ambuehl, Bernheim, and Lusardi (2014), and have proven to be an efficient way to convey the concept of compounding for people broadly unfamiliar with finance and investments. ${ }^{10}$ A question of this sort is particularly relevant for those saving for retirement.

As in many previous studies, we find that the fraction of correct responses is very high for the first three questions, usually referred to as the Big 3. Finding the correct compounded interest rate, on the other hand, is found to be much more difficult for most people. Less than half of the respondents realized that the required rate of return to double the value of an investment over 10 years is lower than $10 \%$, but only $5 \%$ reported that they did not know this.

Following Moore and Healy (2008) and Anderson, Baker, and Robinson (2017), we augment the five standard literacy questions with a question that asks the survey participant to assess the probability for having five, four, three, etc. questions correct. We label the mean of this probability distribution perceived score, and the difference of the financial literacy score and perceived score, overestimation.

To hone in on financial literacy as it pertains to mutual fund choice, our survey includes a question about the importance of fees as opposed to past returns when selecting mutual funds. ${ }^{11}$ The survey also includes questions about attitudes to saving and financial advice. Table II tabulates the responses to two of the main questions besides the financial literacy test. For our questions about mutual fund selection, we ask respondents to agree or disagree to the following statement:

"When selecting a mutual fund, its past returns are more important than its fees"

Possible responses are Strongly agree, Agree somewhat, Disagree somewhat, Strongly disagree and Don't Know. The responses to the questions are tabulated in Panel A and

\footnotetext{
${ }^{10}$ The idea is that the factor 72 gives a first approximation of the effect of compounding and interest, i.e. savings will double in 10 years at an interest rate of $7.2 \%$.

${ }^{11}$ The questions and responses are included in the Internet Appendix.
} 
B of Table II. We find that $44 \%$ agree with the statement, and $11 \%$ strongly so. This is a larger share compared to those who think fees are more important $(29 \%)$. We also find that $25 \%$ respond that they do not know. This is surprising given the effort Swedish policymakers and the SPA have put into informing the public of the importance of fees for future performance when selecting mutual funds, but it is line with other studies. ${ }^{12}$

\section{-Table II here-}

The literature on mutual fund performance is somewhat inconclusive with respect to past returns and fees. On one hand, there is strong support for indexing and minimizing instead of chasing past performance, as suggested by the work of Malkiel (2003) and others. But there is also evidence of momentum in stock returns that carry over to mutual funds, as suggested by Carhart (1997). Dahlquist and Martinez (2015) suggest that neglecting past returns is suboptimal for Swedish pension savers, as inattentive investors tend to be stuck in underperforming funds. It is therefore possible that sophisticated investors find a mix of both past returns and fees to be the best predictor of future performance, but they should never overlook the importance of fees in the long run.

In our analysis, we categorize investors with respect to their views on these two salient, and often discussed, characteristics of mutual funds. We then test empirically how individuals differ depending on their beliefs with respect to overall financial knowledge, self-perceptions, and actual pension fund choice. We choose responses that fall into either side of agreeing or disagreeing somewhat to the returns versus fees statement as our benchmark. The benchmark group is then used for comparing the responses of our three main groups of interest: those who strongly agree (hereafter labeled MF Return), strongly disagree (labeled MF Fee), and contrast those categories to those who do not know (MF Don't know).

Column (4) of Table II shows that those finding fees to be most important to have the highest average literacy score of 3.72 out of 5 , and those who report that they do not know of only 2.34. Having an opinion about past returns or fees is therefore strongly related to the level of financial knowledge, as measured by the literacy test. We find that

\footnotetext{
${ }^{12}$ Choi, Laibson, and Madrian (2010) show that most people fail to pick the lowest cost index fund in an experimental setting; Anderson, Baker, and Robinson (2017) report that most people think past returns more important than fees for determining future performance in a sample of U.S. LinkedIn members. Hastings, Mitchell, and Chyn (2011) find that lower literacy individuals rely less on cost data and more on friends and coworkers when making pension fund decisions.
} 
$25 \%$ of those who find past returns to be most important for future performance are in the default fund at the end of 2015 , whereas $49 \%$ of those who report not knowing never made an active choice.

One of the most important implications of possessing financial knowledge is how it relates to financial engagement. Most studies find strong correlations between scores on the financial literacy test and the propensity for individuals to save and plan for retirement. ${ }^{13}$ But being financially engaged could also drive literacy. Anderson, Baker, and Robinson (2017) find that overestimation to be an important driver for savings and retirement planning decisions, which could be an indication that engagement spurs self-confidence. Direct questions of desirable investment behavior are also likely to be correlated with other biases, such as cognitive dissonance. ${ }^{14}$

\subsubsection{Survey responses}

As we draw randomly from a population with known demographic characteristics, we are able to compare the fractions of individuals taking the survey to the underlying population in Sweden in the working age 18 to 65. Statistics Sweden, who administrated the survey for us, attached population weights to each response based on the characteristics of Table III. The second column Table III presents the sample proportions, and the corresponding composition of the population. Comparing the two, we find much lower response rates for those with lower income, education and age.

-Table III here-

Table III shows that the average score of the test is 3.14 out of possible 5, and as discussed by Lusardi and Mitchell (2008), men generally score higher than women on the test. On average, survey participants thought they scored half a point better than they actually did, with overestimation slightly higher for men than women. Similar to the results of Anderson, Baker, and Robinson (2017), we find that overestimation increases with age, but decreases with the level of education. ${ }^{15}$

\footnotetext{
${ }^{13}$ See Lusardi and Mitchell (2014).

${ }^{14}$ Barber and Odean (1999) find evidence for self-selection in the decision to go online for investors who previously did well, but worse afterwards, and Goetzmann and Peles (1997) show that individuals tend to report overly optimistic assessments of the performance of their mutual fund holdings.

${ }^{15}$ The distribution of beliefs vary systematically across scores, where those who score very well or very poorly are quite confident about the outcome, but where there is considerable uncertainty in the intermediate score categories. We include a plot of this relation in the Internet Appendix.
} 
Next we turn to the demographics of the mutual fund question. Men are more likely to have stronger opinions of both fees and past returns being important for fund choice, while women are twice as likely to report that they do not know. The general pattern of responses to the mutual fund question broadly follows the score of financial literacy across demographic groups. Within the highest income bracket, 15\% think that fees are more important, and $12 \%$ past returns. Only 10\% report that they do not know. This contrasts with the lowest income bracket, where $46 \%$ report that they do not know, but a majority strongly believes past returns are more important than fees for predicting future performance.

The last column in Table III reports the fraction of individuals who were in the default fund at the end of 2015. Overall, a third of our sample was in the default fund, whereas the population weighted average is $39 \%$. This is likely due to the lower representation of young, low income and less educated in our sample as suggested by the first and second column in Table III. For example, our sample only captures 5\% of those in the ages 18-25, though they represent $14 \%$ of the population. The fraction who holds the default fund is $96 \%$ for this group. The fraction holding the default fund drops quickly with age. The strong effects can be explained by the fact that new (and young) entrants in the system did not make an active choice, as evidenced by the results in Table I.

Since young people with low income are also under represented in taking the survey, we re-calculate the sample averages in the first row of Table III using population weights. Scaling up the proportion of this omitted group, we find that the average financial literacy score falls from 3.14 to 2.98 . We also find that the group not knowing if fees or past returns are important for mutual fund selection rises from 0.27 to 0.32 . Adjusting for the omitted group, which is presumably less engaged in financial decisions, can therefore have important implications for interpreting the subsequent results. We therefore opt to include population weights in the preceding analysis when we match the survey results to choice data. 


\subsubsection{Household Planning and Financial Literacy}

The survey also contains a number of questions related to household planning, attitudes and decision-making. ${ }^{16}$ We ask if respondents agree or disagree with the statement: "I find personal financial matters boring." A slight majority (51\%) of survey respondents either agreed or strongly agreed with this statement, and only $2 \%$ responded that they did not know or refused to answer.

Column (1) of Table IV display the result of a Probit regressions where we code a dummy to one if the respondent disagree ( $22 \%$ of respondents) or strongly disagree $(25 \%$ of respondents) with the statement, which we label "Interesting." Interest in finance is strongly related to financial literacy. In Column (2), while controlling for overall financial knowledge, we find that those not knowing the mutual fund question display the greatest lack of interest in financial matters. Among those who think that fees or past returns are important, only the fee group displays interest in finance. We take this as evidence pointing to this group being more sophisticated, even if we cannot formally reject that they are equal when testing the difference in the parameter estimates.

The dependent variable in Columns (3) and (4) of Table IV takes the value one if the respondent reports having thought about how much to save for retirement. Almost $48 \%$ responds yes to this question, which illustrates that Sweden is a country where there is generally a very high awareness of pension planning. Nevertheless, we still find some cross-sectional differences. Planning is more common among high financial literacy, married, older, higher income, and university-educated people. Introducing mutual fund beliefs in Column (4), we find that those who do not know if fees or past returns are more important for fund performance are about $17 \%$ less likely to report that they have tried to figure out how much they need in retirement, which is in support with the notion that these individuals should be the main priority for policy interventions.

\section{-Table IV here-}

We ask if people would be willing to accept free financial advice if it was offered to them, and code a dummy equal one and zero otherwise if the response was yes to this question. Column (5) of Table IV shows that willingness to accept financial advice is higher for

\footnotetext{
${ }^{16} \mathrm{~A}$ complete description of the questions and responses can be found in the Internet Appendix, Table A.2.
} 
females and high income earners, but lower for the married and insignificantly related to general financial literacy. When we introduce mutual fund beliefs in Column (5), we find evidence that those not knowing are in fact reluctant to receive advice. At the other end, we find that those who think past returns are more important than fees are almost 10\% more likely to report that they are willing to accept free financial advice.

In Columns (7) and (8) of Table IV, we model the probability that a respondent reports that they are the sole decision-maker in their household, controlling for marital status. In Column (7), we find that those with higher education and those with higher literacy scores are more likely to be sole decision-makers, but the latter effect is crowded out when introducing beliefs about mutual fund choice. Those thinking past returns rather than fees are more important for mutual fund choice are also more likely to be the sole decision-maker in the household.

The analysis suggests that there are important differences between the groups defined over whether fees or past returns are important. Those who think fees are important display high interest in personal financial matters. Those who think past returns are more important than fees generally lack interest in personal finances, but they are more open to receive financial advice. Furthermore, they are more likely to be decision makers, which raises the concern that they may be particularly exposed to bad or fraudulent financial advice. Finally, those who do not know lack interest in finance, do not plan for retirement, and are reluctant to receive financial advice. This group therefore seems particularly important to target when designing default options, but our results also reveal that they may be difficult to reach due to their lack of engagement.

\section{From General to Specific Financial Literacy}

As discussed in Hastings, Madrian, and Skimmyhorn (2013) and Fernandes, Lynch, and Netemeyer (2014), there is little research about the relationship between general and specific financial knowledge, and its relevance for actual consumer choices in financial markets. The concern is that an increase in general financial knowledge may not be enough to prepare consumers for many relatively sophisticated and infrequent choices, such as mortgages or deciding to participate in the stock market (see Van Rooij, Lusardi, and 
Alessie (2011)).

In this section, we explore correlations between general financial literacy, knowledge about mutual fund choice and interest in personal finance. The latter piece is especially important as policymakers struggle to communicate to younger generations where these decisions are important, but where lack of interest makes it difficult to reach broad layers of this group.

\subsection{Mutual fund responses across score}

Figure 1 traces out Perceived score'-the average self-assessed scores plotted against the actual financial literacy score. We find a systematic overestimation of the outcome among those who score poorly on the test. This is a robust feature of the data, which has been shown in many previous studies of overconfidence. ${ }^{17}$

\section{-Figure 1 here-}

The bars in Figure 1 indicate the fraction of responses about fees and past returns, and they show a clear pattern where those who believe fees to be most important for future performance have higher literacy scores, whereas those who believe past returns to be important are self-confident if not necessarily knowledgeable.

We formally test these correlations in Table V, using a Probit regression on mutual fund responses and financial literacy variables, with controls for socio-demographics. In this analysis, we explore the relation between mutual fund beliefs, actual financial knowledge (as measured by financial literacy score), and perceived score in order to determine the relative importance of self-perceptions and knowledge. In our study, we are not only interested in what people know, but whether they know that they do not know. ${ }^{18}$

A lower test score can originate from two sources: either because the respondent reported the wrong answer, or that they did not know. Thus, we decompose the complement of financial literacy score (ranging from 0 to 5 ) into two parts: Don't know responses (labelled "DK") and the number of mistakes (labelled "Financial Mistakes"), counting the number of mistakes. Since the three variables naturally sums up to five, test scores with

\footnotetext{
${ }^{17}$ See for example Kruger and Dunning (1999), Moore and Healy (2008), and references therein.

${ }^{18}$ In a different survey setting, Müller and Weber (2010) find support for a relation between measures of self-confidence and the propensity to choose actively managed funds.
} 
high meta-cognition should be associated with fewer mistakes, even if the counts of DK responses increase in lower scores.

\section{-Table V here-}

Column (1) shows that a past return response is indeed negatively related to level of education, but positively related to age and financial literacy score. When the perceived score is included in Column (2), it completely crowds out the effect of the financial literacy score. In other words, thinking that past returns is the main determinant of future fund performance is common among those who think they are more literate than they actually are. ${ }^{19}$ This conjecture is supported by the results in Column (3), that shows that respondents thinking that past returns are more important than fees are less likely to be among those responding Don't Know in the financial literacy test, but they are not less likely to report the wrong answer to the question, as given by the insignificant loading on Financial Mistakes. We take this as another indication that these investors display more confidence than competence.

Columns (4) through (6) explore the responses for those thinking fees are more important. In Column (4), higher literacy scores are associated with thinking fees are more important, but in a horse race between actual and perceived literacy, both are significant. The difference in the point estimates on actual and perceived literacy is insignificant, which indicates that while those who think returns are more important think they are more literate than they actually are, those who think fees are more important have a more accurate picture of their financial literacy. Comparing the two groups, those who find minimizing fees to be most important appear to be more sophisticated investors than those focusing on past returns. We find further evidence for this conjecture in Column (6), where this group has a significant lower propensity to give wrong answers to the test. Therefore, we conjecture that they display both confidence and competence. This is in sharp contrast to the results of the past returns group in Column (3).

Columns (7) through (9) of Table V present similar regressions for the group who responded that they do not know whether fees or returns are more important. This group has lower scores and income, and they are also younger compared to the other groups.

\footnotetext{
${ }^{19}$ Strictly speaking, the difference between the loadings on the perceived and actual literacy measures mistaken beliefs about literacy; it is significantly positive here.
} 
Women are roughly 13\% more likely to report that they do not know, an effect size that is roughly equivalent to one additional incorrect answer on the financial literacy test. As in the other regressions, self-perceptions crowd out some of this effect when introduced in Column (8).

The last column of Table V shows that the correlation between responding don't know on the financial literacy test increases the likelihood by $19 \%$ to give the same response to the fee versus past return question. Not knowing the mutual fund question is also associated with a higher number of mistakes, but the marginal effect of DK is three times as large compared to making a mistake. This further supports the notion that those with low mutual fund literacy are less knowledgeable, but also better aware of their lack of competence.

Finally, we find that the nudged cohort, that is those who entered the market in 2000, are much less likely to report that they do not know, whereas the dummy is insignificant for both return and fee responses. One way to interpret this result is that it is evidence that the informational nudge worked: it caused this cohort to be much more likely to form an opinion about the subject of mutual fund choice..$^{20}$

\section{Who Responds to the Nudge?}

To explore how nudges interact with financial literacy and self-awareness to affect retirement savings behavior we examine differences between the nudged cohort and later cohorts in terms of three distinct aspects of program participation. The first is the choice of whether to stay in the default fund or opt out. Second, we examine the tendency to trade exactly once: that is, to opt out of the default fund and never make a subsequent portfolio adjustment. Finally, we examine overall turnover, measured by the number of trades in the funds. To increase the external validity of the estimates we report from our survey, all regressions are weighted with population weights.

\footnotetext{
${ }^{20}$ In untabulated results, we find no evidence that financial literacy is higher or lower for the initial cohort when controlling for the same characteristics as in Table V .
} 


\subsection{Opting out of the Default Fund}

To study whether respondents remain in the default fund option we estimate Probit regressions in which the dependent variable is an indicator variable for having opted out of the default fund as of 2015. The results are presented in the first three columns of Table VI.

Column (1) focuses on the nudged cohort. The variable "Financial literacy," which is formed by summing the number of correct responses to the Big 5 questions, is unrelated to the choice to remain in the default. This illustrates the fact that general financial knowledge is less relevant for the specific knowledge required to make domain-specific choices about mutual funds. The domain-specific questions, however, are more revealing: those who think past returns are more important than fees are over $6 \%$ more likely to opt out of the default fund in the nudged cohort. The effect is large: there is a $14 \%$ difference, significant at the $1 \%$ level, in the marginal probability of opting out between those who think fees are more important and those who think returns are more important. Given that the nudged cohort is about $44 \%$ more likely to opt out conditional on observables (from the parameter estimate in Column(3)), this means that about one-third of the overall effect of the nudge can be explained by differences in financial literacy surrounding mutual funds. Standing in between those who know and those know they don't know are the group with meta-cognition, the group of those who know that they do not know. This group is more likely to stay in the default fund, but not to the same degree in the nudged cohort as those who assert that fees are more important than returns for performance.

Column (2) repeats the same regression but for the later cohorts who did not receive the informational nudge. Here the relation between literacy and opting out is completely different than for the nudged cohort. In the cohorts that did not receive the nudge, there is no different in the marginal probability of opting out between those who think fees are more important and those who think funds are more important. Instead, there is a dramatically higher probability that the "Don't knows" remain in the default fund. In other words, merely having an opinion about the relative importance of fees or returns, rightly or wrongly, is associated with opting out, but having domain-specific knowledge itself has no impact outside the nudge. 
Given the fact that many fewer responses indicated that they did not know the answer to the mutual fund question in the nudge period, the comparison of columns (1) and (2) suggests that the nudge works through two mechanisms: first by encouraging people to form beliefs about the relevant parameters of engagement, and then by encouraging them to act on those beliefs. The fact that the self-aware were much less resolute in their decision to stick with the default fund when exposed to the nudge indicates that the advertising was perhaps reaching an audience of those ill-equipped to handle the decision they were being asked to make.

Column (3) pools the sample and estimates the same model but with a dummy variable for whether a respondent was in the nudged cohort. In addition to confirming the demographic patterns in the first two columns, the point estimate on the initial cohort dummy is itself useful. It indicates that $44 \%$ of the nudged cohort responded to the information intervention on a population-weighted basis.

\subsection{Understanding the Frequency of Trade}

In Columns (4) through (6) of Table VI, the dependent variable equals one for the 445 respondents who traded exactly once. The sample is restricted to those who opted out of the default fund. None of the financial literacy variables that explain the decision to opt out have any power to explain whether individuals trade beyond that initial decision. On the other hand, single-trade investors (those who opt out initially but never trade again) are much more likely to belong to the initial cohort. When we introduce a dummy variable for belonging to the initial cohort in Column (7), we find them to be almost $44 \%$ more likely to belong to this group.

Rather than measuring subsequent trade with a dummy for trading exactly once, columns (7) through (9) replace the dependent variable with a measure of turnover obtained by counting the number of times the portfolio has been rebalanced among those out of the default fund (irrespective of when the individual entered). As before, there is no evidence that returns chasers behave differently than those who think fees are more important in the nudged sample. Among those coming in later, return chasers trade more often but this effect is mainly due to the average higher turnover for the nudged cohort, which we control for in Column (9). This further speaks against the idea that returns- 
oriented respondents pursue momentum strategies that would trigger substantial trading activity.

There is, however, a substantial average effect for the nudged cohort. This group trades on average more than twice as often as those coming into the system in later cohorts. This difference is considerably larger than what would occur if the probability of trade were proportional to the passage of time, and remains after controlling separately for the individual retirement cohorts.

In sum, possessing domain-specific financial literacy is a robust predictor of who responded to the initial informational nudge, but has little power to predict what happens after they have been nudged. The variation in knowledge that predicts opting out does not predict subsequent trading activity. Nevertheless, the nudged group was both more likely to never trade again and more likely to be a frequent trader. The next section explores what is responsible for this apparent contradiction.

\subsection{Mass-Market Advisors}

As we discussed in Section 2, coordinated trades by financial advisors play an important role in driving the turnover studied in the previous section. ${ }^{21}$ In this section, we study how the uptake of such financial services is related to financial literacy. Because we are interested in providing quantitative magnitudes that reflect the broader population, we apply sampling weights to some regression specifications.

-Table VII here-

Table VII reports Probit regressions in which the dependent variable equals one if the respondent in question is classified as having used a mass-market advisor (MMA) and zero otherwise. Because advisors operate at different levels of market scope, the table includes separate analyses depending on how widely the trades in question occurred. Columns (1) through (3) counts a respondent as being affiliated with an advisor if at least 1,000 coordinated trades occurred, which resulted in 353 investors being classified as having subscribed to an advisor. This definition probably covers many different types of

\footnotetext{
${ }^{21}$ Indeed, if we include a dummy variable for mass-market advisor (as described below) into the turnover regressions in Table VI we find that it has a highly significant positive loading. Results are available upon request.
} 
advisors, including MMA's. Column (4) through (6) only counts respondents associated with trades in the upper half of the distribution of coordination size (or at least 12,535 identical portfolio rebalances in a sample of 480,000 retirement accounts), valid for 220 investors in sample. The independent variables MF Return, MF Fee and MF Don't Know are dummy variables for the three categories of mutual fund financial literacy (answers to the statement "When selecting a mutual fund, its past returns are more important than its fees" as discussed above).

Overall, Table VII shows that respondents with higher actual literacy scores are somewhat less likely to use mass-market advisors, and significantly so when narrowing the definition of MMA's. In addition, mistaken beliefs about mutual fund selection criteria are associated with increased uptake of such services, while correct beliefs about mutual fund selection criteria are associated with decreased uptake. Columns (4) to (6) show that there are significant links between mutual fund literacy and uptake, and that this effect is generally coming from the nudged cohort. Note too that these effects are not present in Columns (1) through (3), which suggests that advisory firms with mass appeal appear to attract less sophisticated investors who were nudged to make an active choice in 2000.

It is important to stress that we cannot attach a causal interpretation to the point estimates on financial advisor in Table VII. The tabulated results are consistent with alternative explanations, each interesting in their own right. One is that retirement advisors convince investors to entrust them with their retirement accounts by persuading them that returns are important and promising that they can deliver superior performance. They then incorporate these statements into their beliefs about how mutual fund markets function, and we then measure their understanding of the importance of past returns as a consequence of this. The second is that by holding the belief that returns are more important than fees, people are more likely to succumb to the marketing pressure of the tele-marketing organizations. Both explanations square with existing evidence in the literature on the incentives of advisors, as in Linnainmaa, Melzer, and Previtero (2015). In this sense, the weak results for less widespread coordination of trades may suggest that larger and more successful advisors are among the more aggressive in marketing investment advice.

As discussed earlier, many MMA's opened high-fee fund-of-funds in the wake of 
changing regulations that made it more difficult to operate through coordinated trades across a large number of investors. The SPA names 15 fund families and 61 funds that originate from advisory firms having a majority fund-of-fund construction, of which 41 appear in our data. According to the SPA, these companies had almost 600,000 clients as of 2014 which is about $10 \%$ of the total number of people in the pension system. ${ }^{22}$ These funds are on, average, much more expensive for investors. The average equity fund fee for advisor funds is $65 \mathrm{bps}$, compared to $51 \mathrm{bps}$ in the full sample.

\section{-Table VIII here-}

As a further test of assessing the propensity to sign up for MMA services, we estimate the probability of holding one of these funds in 2015 as a function of investor characteristics and financial literacy. Again, these regressions are estimated with sampling weights. Columns (1) through (3) of Table VIII show that those with lower financial literacy and strongly believing past returns are important for performance are more likely to hold these funds compared to the benchmark group, but this only for the nudge cohort. People in the nudged cohort are $9.1 \%$ more likely to end up with a mass market advisor, but even controlling for this general effect, return chasers are much more likely to hold these funds. In Column (4), we include an indicator variables for having participated in a coordinated change measured on the two different levels of coordinated changes. The point estimates in Columns (4) and (5) reveal that the median coordinated change (labelled "MMA / 50th", with over 12,000 coordinated changes) gives the highest prediction (with a marginal probability of $41.7 \%$ ) of holding one of the MMA managed funds. At the same time, the point estimate for MF Return becomes attenuated as we expand the scope of the advisory firm, indicating that the main channel by which returns-oriented investors take up advisory-led fund of funds is through their prior affiliation with the more mass-market advisory firms.

\footnotetext{
${ }^{22}$ Effekter av massfondbytesstoppet, PM Pensionsmyndigheten, PID119386. The five largest firms listed are Monetar, Solitar, Allra, Indecap and Advisor, which together have close to half a million customers according to the estimates.
} 


\section{The Consequences of Fund Choices}

Up to this point, the analysis shows that less financially literate respondents are more likely to opt out of the default fund and that a good deal of this comes from reliance on mass-market retirement investment planners, which coordinate trades across large numbers of individuals. The final step of the analysis explores the welfare implications of these decisions for the investors who make them. We do this by first examining the fees (not including any fees paid directly to retirement investment coordinators) and then by examining net-of-fee performance.

\subsection{Fees}

Table IX reports OLS regressions of the fees associated with mutual fund choices. The independent variables include literacy, demographics, fund characteristics and whether the respondent used an advisor.

-Table IX here-

Columns (1) and (2) omit mutual fund literacy and focus on the role that MMA's play in mutual fund fees. Individuals who use retirement advisors pay substantially higher fees. Column (1) does not control for the type of mutual fund in question (there is substantial variation in average fees by fund type) and shows that advisor-related respondents pay 7.6 basis points more per year, on a population-weighted basis, compared to other individuals who opt out without using an advisor. Given that the conditional mean fee given by the intercept of the regression is around 30.8 basis points and the cost for the default fund is 12 basis points, this effect is substantial both economically and statistically. Respondent demographics play little role in explaining fees in the sub-sample of those who have opted out of the default fund.

Column (2) adds the weights in each respondent's portfolio on each of the four fund types of funds in our data. Because the weights naturally sum to one, the constant term is omitted. When we control for the composition of fund types, we see that advisoraffiliated respondents still face higher fees; the coefficient for the MMA dummy drops to 6.1 basis points. Thus, the higher fees associated with advisor-managed accounts do not 
stem from the fact that they tilt investors more into one asset class than another: within asset classes they are choosing the higher fee funds available.

Column (3) removes the advisor variable but adds the three variables that capture mutual fund literacy. This column shows that investors who think past returns are more important pay higher fees on average. Again, this is estimated on the subsample of those who opted-out, so the increased tendency for these types to leave the default fund is not responsible for the magnitude of this point estimate. It is based on a comparison with other investors who opted out of the default fund but held different beliefs about the factors that are important for mutual fund selection. Although the effects are not precisely estimated, the loadings on mutual fund fees and on self-awareness indicate that both types pay lower fees, with those who know the importance of fees paying less than those who are unsure.

Advisor selection and mutual fund literacy are jointly considered in Column (4). Here both sets of variables are important. Advisor-affiliated respondents pay about 5.9 basis

points more in fees per year, even holding constant their financial literacy. Finally, Column (5) repeats Column (4) but includes the full sample. This changes the interpretation of the point estimate for the advisor dummy variable, because the comparison group is now all individuals who did not choose an advisor, including those who stayed with the default fund. The results are even stronger when benchmarked against those individuals who kept the default choice with an estimated difference of 8.5 basis points. People in the nudged cohort pay an additional 7 basis points higher fees on average compared to later entrants which we associate with their higher propensity to opt out. Those with high meta-cognition, not knowing about fees or past returns, are more likely to stay in default and so pay 3.2 basis points lower fees, controlling for the nudge and the measured mass-market advisor activity.

\subsection{Performance}

In the final part of our analysis, we investigate how mutual fund literacy and reliance on outside advisors impacts performance. We take several approaches to performance measurement where we have computed monthly returns from daily holdings and prices. 
First, we derive an average raw excess returns over the default fund return as follows:

$$
A P 7_{i}=\frac{1}{T} \sum_{t=1}^{T}\left(R_{i, t}-R_{A P 7, t}\right) .
$$

This provides a measure of performance relative to the return one would have earned had one not opted out of the default fund. Second, use a standard factor model that includes a Swedish and Global value weighted index and three other factor exposures. Formally, we estimate

$$
R_{i, t}=\alpha_{i}+\beta_{i, S} R_{S, t}+\beta_{i, G} R_{G, t}+\beta_{S M B, i} R_{S M B, t}+\beta_{H M L, i} R_{H M L, t}+\beta_{M O M, i} R_{M O M, t}+e_{i, t},
$$

where $R_{S, t}$ and $R_{G, t}$ denote the monthly Swedish and Global equity excess returns and $R_{S M B, t}, R_{H M L, t}$, and $R_{M O M, t}$ denote the size, value and momentum zero cost portfolios obtained from the Swedish House of Finance website. ${ }^{23}$ We present results for both the full model and those excluding the zero-cost factor portfolios.

\section{-Figure 2 here-}

Figure 2 plots the distribution of annualized market-model alphas for those who have opted out of the default. The dark-shaded region of the graph corresponds to those who underperform the benchmark. The annualized mean performance is around negative $1.3 \%$ per year, and the median is slightly lower. The upper (lower) decile of the alphas is $1.4 \%(-3.9 \%)$. Only $21 \%$ of the active investors have non-negative alphas.

Table X examines how performance is related to participant characteristics for the full sample in OLS-regressions. The median annualized Sharpe ratio in our sample is approximately 0.27 , but there is significant variation according to the literacy of the respondent and their reliance on advisors. Column (1) shows that those who think fees are important in the nudged sample have significantly higher Sharpe ratios, and the difference between those believing past returns to be important is significant. The parameter estimates imply an average difference in Sharpe ratios of over 15\%. There is a smaller, but significant relation between having higher financial literacy and higher Sharpe ratios, which is four times smaller compared to mutual fund literacy. The group who do not know also have

\footnotetext{
${ }^{23}$ All benchmarks are value weighted. The data was retrieved from the Swedish House of Finance website at https://data.houseoffinance.se/.
} 
significantly higher Sharpe ratios in the full sample, but they are also more likely to be in the default fund. In Column (3), we include a dummy for those classified as having an advisor in the full sample, which shows that are being associated with a mass-market advisor have 0.074 lower average Sharpe-ratios. Like in the previous analysis, the inclusion of the dummy attenuates some of the effects coming from mutual fund beliefs. To put this point estimate in perspective, the loading on MMA in Column (3) corresponds to around $1 \%$ lower annual return holding constant the annual standard deviation.

\section{-Table X here-}

The remaining columns of the table replace the Sharpe ratio with abnormal returns obtained from the AP7 benchmark, a market model, or the extended Fama-French-Carhart model. The results are broadly consistent with those of the first three columns. Those finding past returns (fees) to be important for mutual fund selection underperform (outperform) by 27 to 32 (25 to 28 ) basis points per year on average in the full sample when we do not control for MMA's. When controlling for MMA's, this effect becomes less pronounced, but the difference in performance between the groups are only significant in both model specifications. The negative loadings on the mass-market advisor variable range from an underperformance of $0.5 \%$ to $1.1 \%$ per year. This underscores the fact that the Sharpe ratio differences come not just from choosing funds with lower average returns, but also with excessive volatility for the returns achieved. The "Don't know" category also do better on a risk-adjusted basis than the past returns group, but not significantly so in the nudged cohort. Our robustness analysis shows that this is driven largely by their greater propensity to remain in the outperforming default fund, and to some extent a greater propensity to avoid expensive advisor-led fund-of-funds. Related to this, we also find some evidence that general financial literacy is associated with better performance. By comparing the point estimates in Columns (10) through (12), we draw the conclusion that the main channel for this is not related to better fund choices per se, but them having a lower propensity to opt out of the default fund and to follow mass-market advisors.

Taken together, the results in Table $\mathrm{X}$ indicate that returns-oriented investors and investors who rely on mass-market advisory firms have significantly worse retirement savings outcomes than either those who know the importance of low fees, or else know of 
their own ignorance in the matter. These findings are robust to changing the sample period to account for the banning of coordinated trading in 2011, and also to changes in the construction of the default fund. ${ }^{24}$

\section{Conclusion}

Some of the most important long-run financial decisions facing households throughout the world play out in market settings where household decision-makers must confront persuasion and strategic obfuscation as they search to collect the relevant information required to make appropriate choices. Behavioral biases and the choice architecture itself not only affect how households make decisions, they also affect the very incentives for strategically generating information by other market participants. Understanding how these factors interact is critical not only for designing effective economic policy, but also for understanding more generally how cognitive factors and market structures affect the manner in which information is incorporated into household financial decisions.

Sweden's pension reform experience offers a natural laboratory for studying these interactions. The Swedish system offers a low-cost, well-diversified default fund along with the opportunity to choose among an enormous number of alternative mutual funds; moreover, the initial cohort received a strong informational nudge encouraging them to actively manage their retirement portfolio while later cohorts did not. Thus, through the Swedish experience we can study how behavioral biases and knowledge affect who responds to informational nudges, acknowledging that the informational nudge itself shapes the market structure facing pension savers.

We find that individuals with mistaken beliefs about their own general financial literacy are also prone to hold mistaken beliefs about the factors important for making mutual fund allocation decisions. These mistaken beliefs have negative consequences: individuals who hold them are steered away from a well-diversified, low-cost default mutual fund into low-performing, higher-cost alternatives. This is especially true among the cohort of individuals who were nudged to make an active choice-the respondents who felt the nudge the most were those who misunderstood the factors important for making mutual

\footnotetext{
${ }^{24}$ These results are available upon request.
} 
fund choices.

In contrast, individuals in our study who find finance uninteresting and are generally disengaged from financial decision-making are well protected by the plan's default structure. These are exactly the investors best served by a choice architecture designed to guard against costly indecision. Nevertheless, the informational nudge undermined this feature of the system, pulling the otherwise disengaged into the mutual fund choice process.

These results underscore the need for a better understanding of the connection between knowledge, self-awareness and choice architecture. A system that allows individuals to opt out of a default not only provides choice, it creates markets for information and advice. Taking this into account is critical for our understanding of how to balance the costs of sub-optimal decision-making from certain groups against the benefits associated with greater freedom of choice in a market setting where consumer financial knowledge is both heterogeneously distributed and essential for participation. 


\section{References}

Agell, Jonas, Peter Englund, and Jan Södersten, 1995, The Swedish tax reform: An introduction, Swedish Economic Policy Review 2, 219-228.

Ambuehl, Sandro, B. Douglas Bernheim, and Annamaria Lusardi, 2014, The effect of financial decision education on the quality of decision making, National Bureau of Economic Research Working Paper 20618.

Anagol, Santosh, and Hugh Hoikwang Kim, 2012, The impact of shrouded fees: Evidence from a natural experiment in the indian mutual funds market, American Economic Review 102, 576-593.

Anderson, Anders, Forest Baker, and David T. Robinson, 2017, Precautionary savings, retirement planning and misperceptions of financial literacy, Journal of Financial Economics 126, 383-398.

Barber, Brad M., and Terrance Odean, 1999, The courage of misguided convictions, Financial Analysts Journal 55, 10-18.

Beshears, John, James J. Choi, David Laibson, and Brigitte C. Madrian, 2006, The importance of default options for retirement saving outcomes: Evidence from the United States, in Jeffrey R. Brown, Jeffrey B. Liebman, and David A. Wise, ed.: Social Security Policy in a Changing Environment . pp. 167-195 (NBER).

— , and Sean (Yixiang) Wang, 2016, Who is easier to nudge?, Working paper, Harvard University.

Beshears, John, James J. Choi, Brigitte C. Madrian, and Katherine L. Milkman, 2015, The effect of providing peer information on retirement savings decisions, Journal of Finance 70, 1161-1201.

Burke, Jeremy, Angela Hung, Jack Clift, Steven Garber, and Joanne Yoong, 2015, Impacts of conflicts of interest in the financial services industry, Discussion paper RAND.

Campbell, John Y., 2006, Household finance, Journal of Finance 61, 1553-1604.

Carhart, Mark M., 1997, On persistance in mutual fund performance, Journal of Finance $52,57-82$.

Carroll, Gabriel D., David Laibson, Brigitte C. Madrian, and Andrew Metrick, 2009, Optimal defaults and active decisions, Quarterly Journal of Economics 124, 1639-1674.

Choi, James J., David Laibson, and Brigitte C. Madrian, 2010, Why does the law of one price fail? an experiment on index mutual funds, Review of Financial Studies 23, 14051432.

, and Andrew Metrick, 2004, For better or for worse: Default effects and 401(k) savings behavior, in David A. Wise, ed.: Perspectives in the Economics of Aging . pp. 81-121 (University of Chicago Press). 
- 2006, Saving for retirement on the path of least resistance, in Edward J McCaffery, and Joel Slemrod, ed.: Behavioral Public Finance: Toward a New Agenda . pp. 304-351 (Russell Sage Foundation).

Cronqvist, Henrik, and Richard H. Thaler, 2004, Design choices in privatized socialsecurity systems: Learning from the Swedish experience, American Economic Review, Papers and Proceedings 94, 424-428.

— , and Frank Yu, 2018, When nudges are forever: Inertia in the swedish premium pension plan, Working paper, University of Chicago.

Dahlquist, Magnus, and José Martinez, 2015, Investor inattention: A hidden cost of choice in pension plans?, European Financial Management 21, 1-19.

- and Paul Söderlind, 2017, Individual investor activity and performance, Review of Financial Studies 30, 866-899.

Fernandes, Daniel, John G. Lynch, and Richard G. Netemeyer, 2014, Financial literacy, financial education, and downstream financial behaviors, Management Science 60, 18611883.

Goetzmann, William N., and Naday Peles, 1997, Cognitive dissonance and mutual fund investors, Journal of Financial Research 20, 145-158.

Hastings, Justine, Olivia S. Mitchell, and Eric Chyn, 2011, Fees, framing, and financial literacy in the choice of pension managers, in Olivia S. Mitchell, and Annamaria Lusardi, ed.: Financial Literacy: Implications for Retirement Security and the Financial Marketplace (Oxford University Press).

Hastings, Justine S., Brigitte C. Madrian, and William L. Skimmyhorn, 2013, Financial literacy, financial education, and economic outcomes, Annual Review of Economics 5, 347-373.

Kim, Hugh Hoikwang, Raimond Maurer, and Olivia S. Mitchell, 2016, Time is money: Rational life cycle inertia and the delegation of investment management, Journal of Financial Economics 121, 231-248.

Kruger, Justin, and David Dunning, 1999, Unskilled and unaware of it: How difficulties in recognizing one's own incompetence lead to inflated self-assessments, Journal of Personality and Social Psychology 77, 1121-1134.

Linnainmaa, Juhani, Brian T. Melzer, and Alessandro Previtero, 2015, Costly financial advice: Conflicts of interest or misguided beliefs?, Working Paper w20712, NBER.

Lusardi, Annamaria, Pierre-Carl Michaud, and Olivia S. Mitchell, 2017, Optimal Financial Knowledge and Wealth Inequality, Journal of Political Economy 125, 431-477.

Lusardi, Annamaria, and Olivia S. Mitchell, 2008, Planning and financial literacy: How do women fare?, American Economic Review 98, 413-417. 
_ _ 2011, Financial literacy and planning: Implications for retirement well-being, in Annamaria Lusardi, and Olivia S. Mitchell, ed.: Financial Literacy: Implications for Retirement Security and the Financial Marketplace . pp. 17-39 (Oxford University Press) Michigan Retirement Research Center, WP 2015-108.

_ 2014, The economic importance of financial literacy: Theory and evidence, Journal of Economic Literature 52, 5-44.

Madrian, Brigitte C., and Dennis F. Shea, 2001, The power of suggestion: Inertia in 401(k) participation and savings behavior, Quarterly Journal of Economics 116, 1149-1187.

Malkiel, Burton G., 2003, The efficient market hypothesis and its critics, Journal of Economic Perspectives 17, 59-82.

Moore, Don, and Paul J. Healy, 2008, The trouble with overconfidence, Psychological Review 115, 502-517.

Müller, Sebastian, and Martin Weber, 2010, Financial literacy and mutual fund investments: Who buys actively managed funds?, Schmalenbach Business Review 62, 126-153.

Palme, Marten, Annika Sunden, and Paul Söderlind, 2007, How do individual accounts work in the swedish pension system?, Journal of the European Economic Association 5, 636-646.

Thaler, Richard H., and Cass R. Sunstein, 2008, Nudge (Yale University Press).

Van Rooij, Maarten, Annamaria Lusardi, and Rob Alessie, 2011, Financial literacy and stock market participation, Journal of Financial Economics 191, 449-472. 


\section{Table I: Pension funds and holdings}

This table reports characteristics of the funds in the sample. Panel A reports the investments and fees across six broad fund categories. Since 2010, default fund savers automatically obtain an increasing allocation to the default bond fund after the age of 56. Fees are reported net of discounts, but excludes the service fee charged to all accounts by the Swedish Pensions Agency (SPA). Panel B reports the number of individuals who were in the default fund at the end of 2000 - the year which the pension system was introduced. The following columns report the number of new savers who entered after 2000; those who opted out of default up until 2015; and the number of individuals in the default fund at the end of 2015. The last column of Panel B reports the number of people trading only once, out of the default fund at the end of 2015. The data is obtained from the SPA and matched to our sample of 2,502 survey respondents. Panel C reports frequencies for respondents and trades that are associated with mass-market advisors, where advisor-led trades are defined according to three different criteria from a sample of 480,000 retirement accounts: a trade coincides with at least 1,000 other identical trades on the same day, a trade coincides with a number exceeding the $25^{\text {th }}$ percentile of coordinated trades, or a trade coincides with trades that involve more than the median number of coordinated trades.

Panel A: Pension fund types, investments and fees

\begin{tabular}{lrrrrrrr}
\hline & & & & & \multicolumn{3}{c}{ Fees, BPs } \\
\cline { 5 - 8 } Fund type & No. of & No. of & Value & Share & Q 1 & Med. & Q 3 \\
& funds & invest. & 2015 & of value & & \\
\hline Default equity fund & 1 & 789 & 86.67 & $23 \%$ & 12 & 12 & 12 \\
Default bond fund & 1 & 155 & 4.80 & $1 \%$ & 5 & 5 & 5 \\
Equity funds & 336 & 3,152 & 183.21 & $48 \%$ & 33 & 51 & 70 \\
Mixed funds & 57 & 375 & 31.28 & $8 \%$ & 35 & 38 & 5 \\
Target date funds & 30 & 587 & 63.31 & $17 \%$ & 18 & 20 & 20 \\
Bond funds & 68 & 277 & 13.20 & $3 \%$ & 12 & 19 & 36 \\
\hline Total & 493 & 5,335 & 382.47 & $100 \%$ & 25 & 40 & 62
\end{tabular}

Panel B: Active and passive choice

\begin{tabular}{lrrrrr}
\hline Fund choice & 2000 & $\begin{array}{r}\text { New } \\
\text { default }\end{array}$ & $\begin{array}{r}\text { Opted } \\
\text { entrants }\end{array}$ & $\begin{array}{r}2015 \\
\text { out }\end{array}$ & $\begin{array}{r}\text { One } \\
\text { default }\end{array}$ \\
\hline Default fund & 422 & 505 & -73 & 854 & 445 \\
Other & 1,346 & 229 & 73 & 1,648 & 2,057 \\
\hline Total & 1,768 & 734 & 0 & 2,502 & 2,502 \\
Fraction (Default/Trade) & $24 \%$ & $69 \%$ & - & $34 \%$ & $18 \%$
\end{tabular}

Panel C: Trades Coordinated through Mass-Market Advisors

\begin{tabular}{lrr}
\hline Coordination & Respondents & \multicolumn{1}{c}{ Trading } \\
Threshold & $\mathrm{N}=2,502$ & Tot. trades $=18,566$ \\
\hline At least 1,000 trades & $353(14.1 \%)$ & $10,884(58.6 \%)$ \\
$25^{\text {th }}$ percentile & $330(13.2 \%)$ & $10,393(56.0 \%)$ \\
Median & $220(8.8 \%)$ & $6,345(34.2 \%)$
\end{tabular}



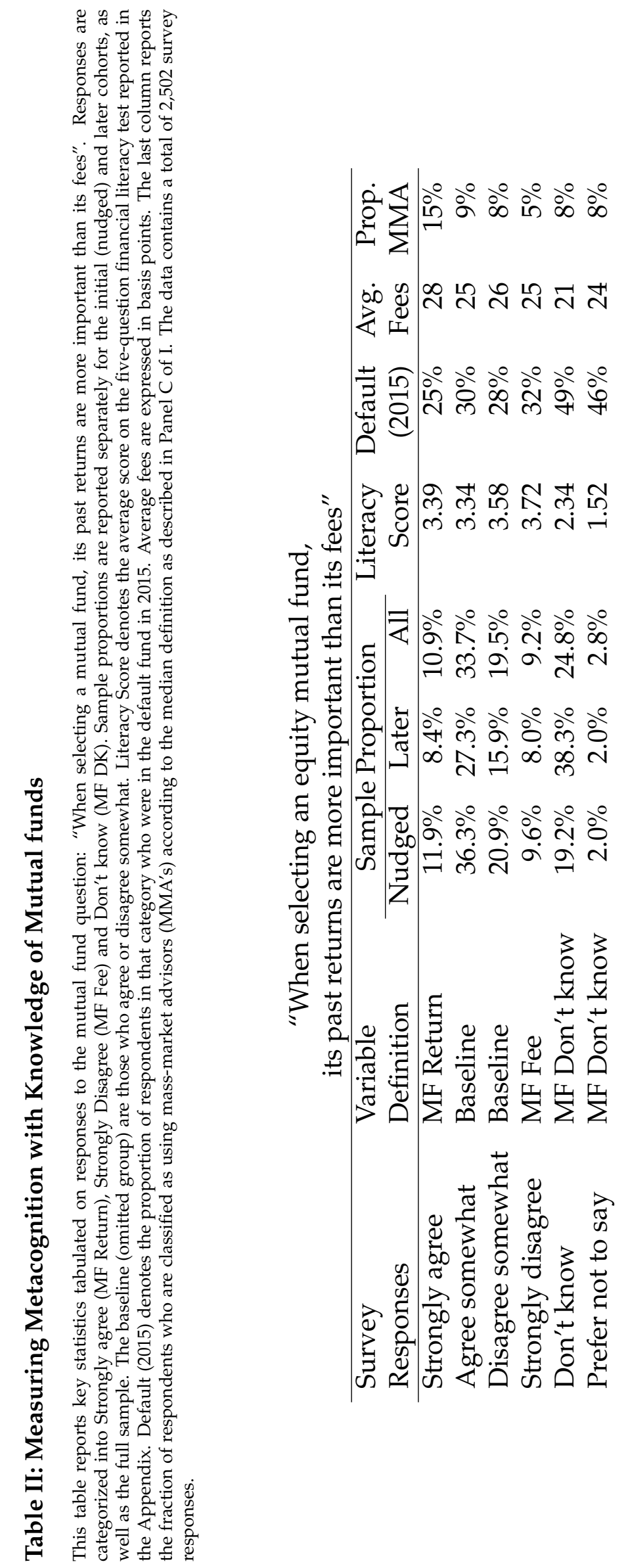


\section{Table III: Respondent Characteristics}

This table tabulates the responses from the survey based on individual characteristics. The first two columns report the fraction of responses compared to the sample population. The third and fourth columns report the average score on the financial literacy test, along with Overestimation, which is the difference between the respondent's subjective estimate of their score and their actual score. Columns (5)-(7) reports fraction of responses to the mutual fund question described in Table II, and the last column the fraction of people in the default fund at the end of 2015. The survey was conducted by Statistics Sweden and matched to data from the Swedish Pensions Agency and consists of 2,502 observations.

\begin{tabular}{|c|c|c|c|c|c|c|c|c|}
\hline & \multirow{2}{*}{$\begin{array}{c}\text { Sample } \\
\text { Prop. }\end{array}$} & \multirow{2}{*}{$\begin{array}{l}\text { Pop. } \\
\text { Prop. }\end{array}$} & \multirow{2}{*}{$\begin{array}{c}\text { Fin. Lit. } \\
\text { Score }\end{array}$} & \multirow[b]{2}{*}{ Overest. } & \multicolumn{3}{|c|}{ Mutual Fund: } & \multirow{2}{*}{$\begin{array}{r}\text { Defau. } \\
\text { Fund }\end{array}$} \\
\hline & & & & & Return & Fee & $\mathrm{D} / \mathrm{K}$ & \\
\hline Overall & 100.00 & 100.00 & 3.14 & 0.50 & 0.11 & 0.09 & 0.27 & 0.34 \\
\hline Pop. Wtd. & - & - & 2.98 & 0.52 & 0.11 & 0.08 & 0.32 & 0.39 \\
\hline \multicolumn{9}{|l|}{ Gender } \\
\hline Men & 50.04 & 50.90 & 3.48 & 0.53 & 0.13 & 0.11 & 0.17 & 0.33 \\
\hline Women & 49.96 & 49.10 & 2.81 & 0.48 & 0.09 & 0.07 & 0.37 & 0.35 \\
\hline \multicolumn{9}{|l|}{ Age } \\
\hline $18-24$ & 5.36 & 14.40 & 2.81 & 0.25 & 0.07 & 0.05 & 0.50 & 0.96 \\
\hline $25-34$ & 16.39 & 21.70 & 3.09 & 0.29 & 0.09 & 0.08 & 0.40 & 0.64 \\
\hline $35-44$ & 20.18 & 21.00 & 3.15 & 0.44 & 0.12 & 0.11 & 0.26 & 0.30 \\
\hline $45-54$ & 28.22 & 21.80 & 3.21 & 0.56 & 0.11 & 0.11 & 0.22 & 0.17 \\
\hline $55-65$ & 29.86 & 21.10 & 3.17 & 0.65 & 0.12 & 0.08 & 0.21 & 0.25 \\
\hline \multicolumn{9}{|l|}{ Income } \\
\hline $0-124$ & 9.11 & 23.90 & 2.91 & 0.42 & 0.08 & 0.06 & 0.46 & 0.63 \\
\hline $125-274$ & 37.85 & 41.50 & 2.78 & 0.57 & 0.10 & 0.07 & 0.36 & 0.40 \\
\hline $275-374$ & 29.98 & 21.20 & 3.21 & 0.53 & 0.11 & 0.08 & 0.21 & 0.27 \\
\hline $375+$ & 22.42 & 13.40 & 3.78 & 0.41 & 0.12 & 0.15 & 0.10 & 0.2 \\
\hline
\end{tabular}

Education

Some school

High school

College

$\begin{array}{rrrrrrrr}6.08 & 16.00 & 2.60 & 0.68 & 0.08 & 0.09 & 0.38 & 0.28 \\ 38.85 & 45.80 & 2.82 & 0.65 & 0.12 & 0.07 & 0.30 & 0.29 \\ 54.84 & 38.20 & 3.43 & 0.38 & 0.11 & 0.11 & 0.23 & 0.38\end{array}$




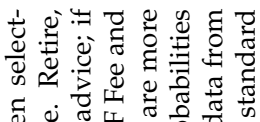

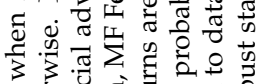

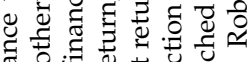

苞

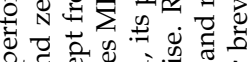

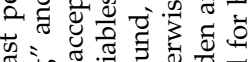

范

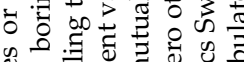

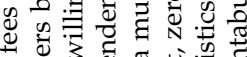

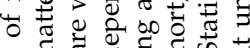

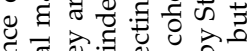

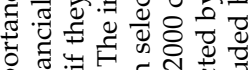

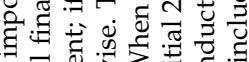

\&

士

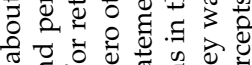

क

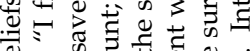

\&ี

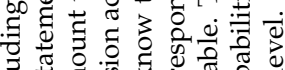

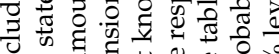

ఏ

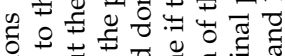

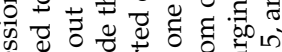

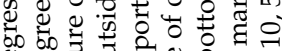

車

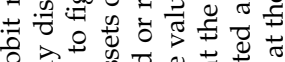

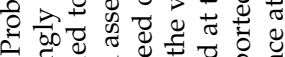

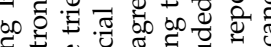

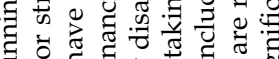

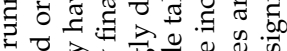

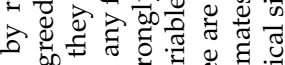

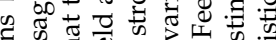

.0

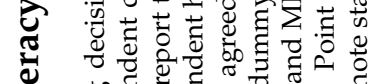

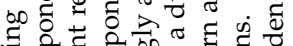

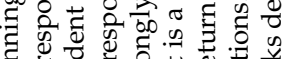

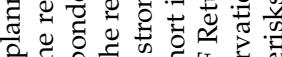

들 की

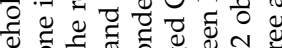

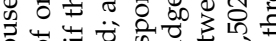

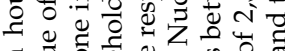

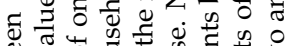

उ.

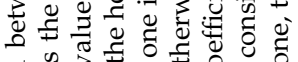

○ี

寻

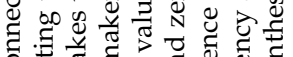

ठิ

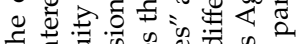

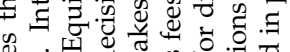

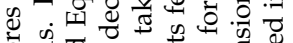

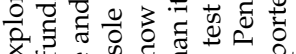

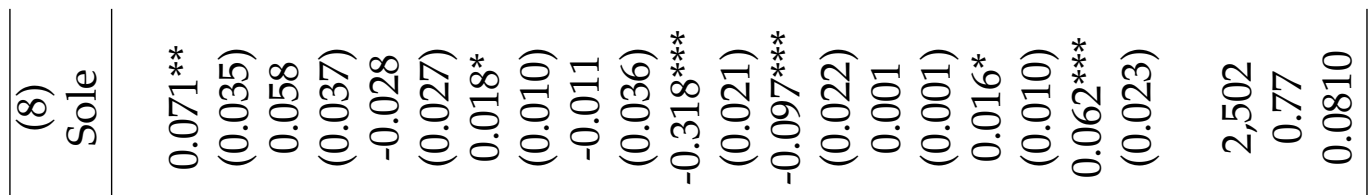

હ $\frac{0}{8}$

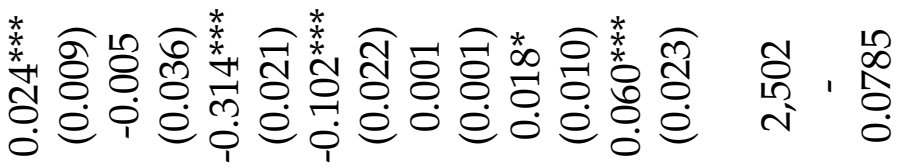

$6 \frac{0}{\frac{0}{2}}$

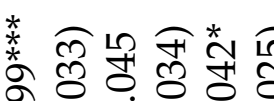

ลิ่งสำ

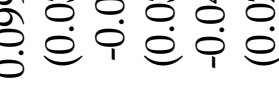

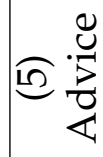

Æ产

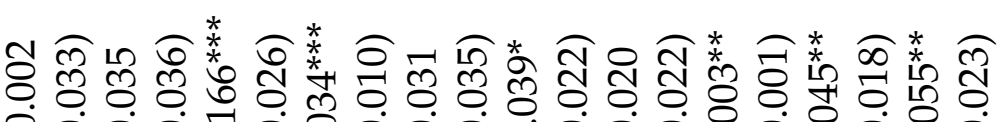

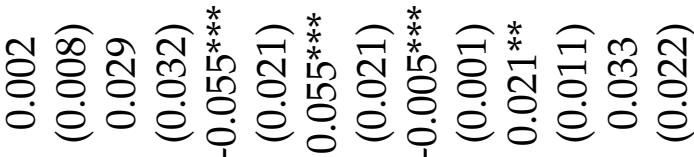

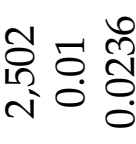

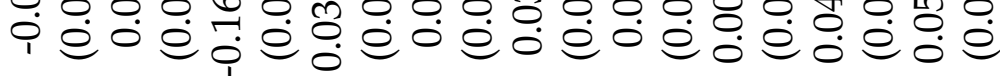

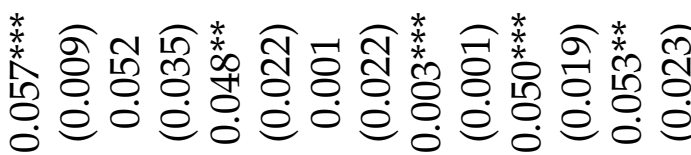

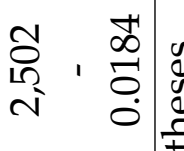

ลํ.

高蓠

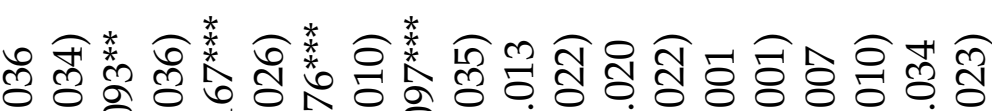

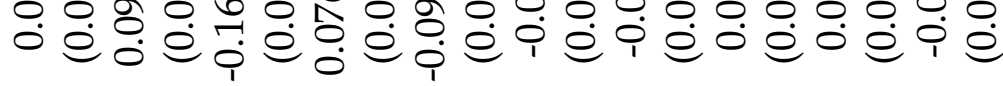

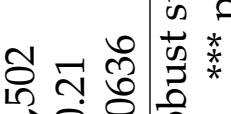

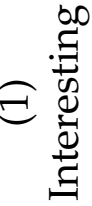

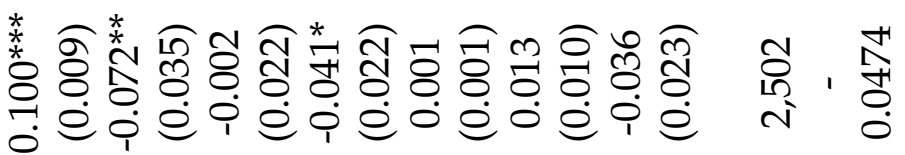

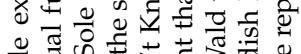

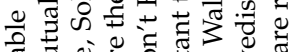

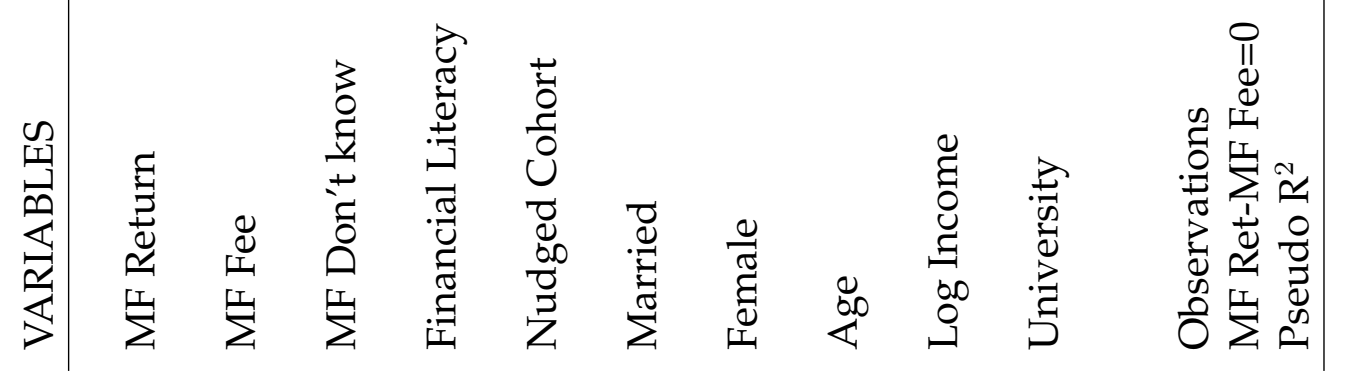




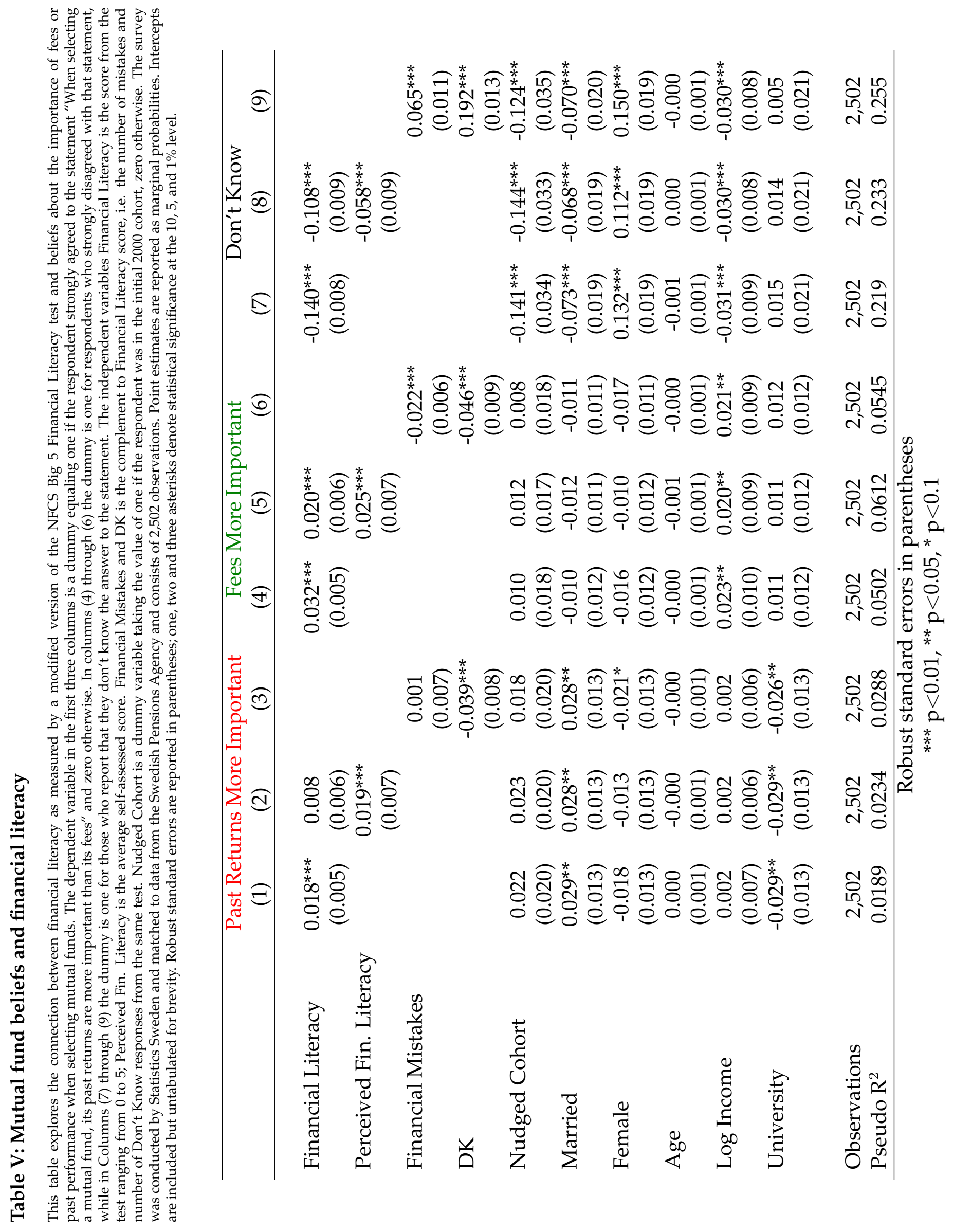




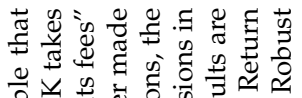

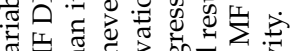

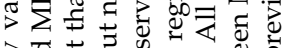

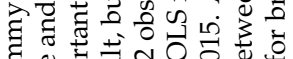

๕ष

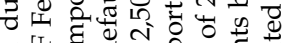

๙

क छ

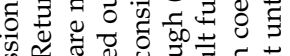

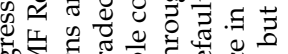

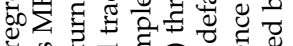

¿

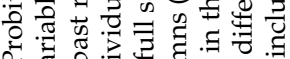

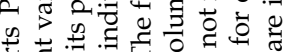

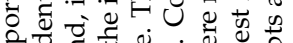

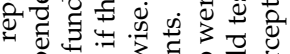

त्र क्षँ

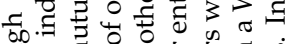

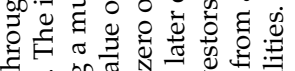

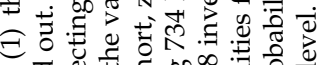

里

क

5 뒁 웅

○

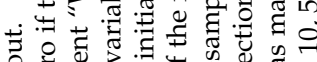

ठ월

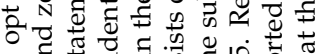

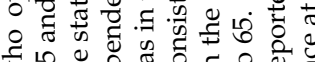

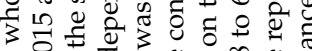

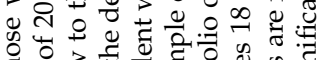

F

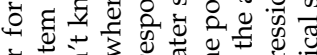

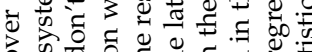

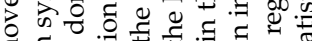

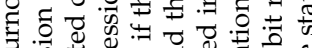

\pm क

응

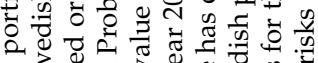

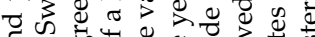

व

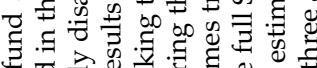

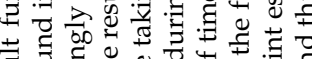

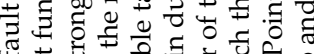

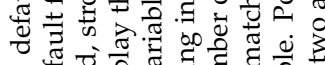

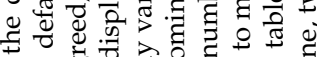

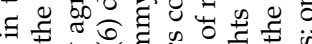

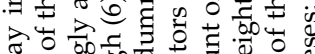

के

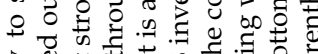

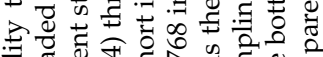

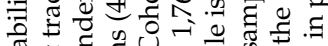

范

눙 क्ष

东U

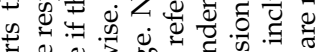

范

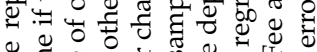

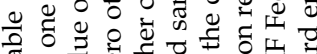

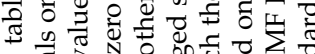

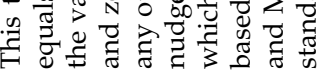

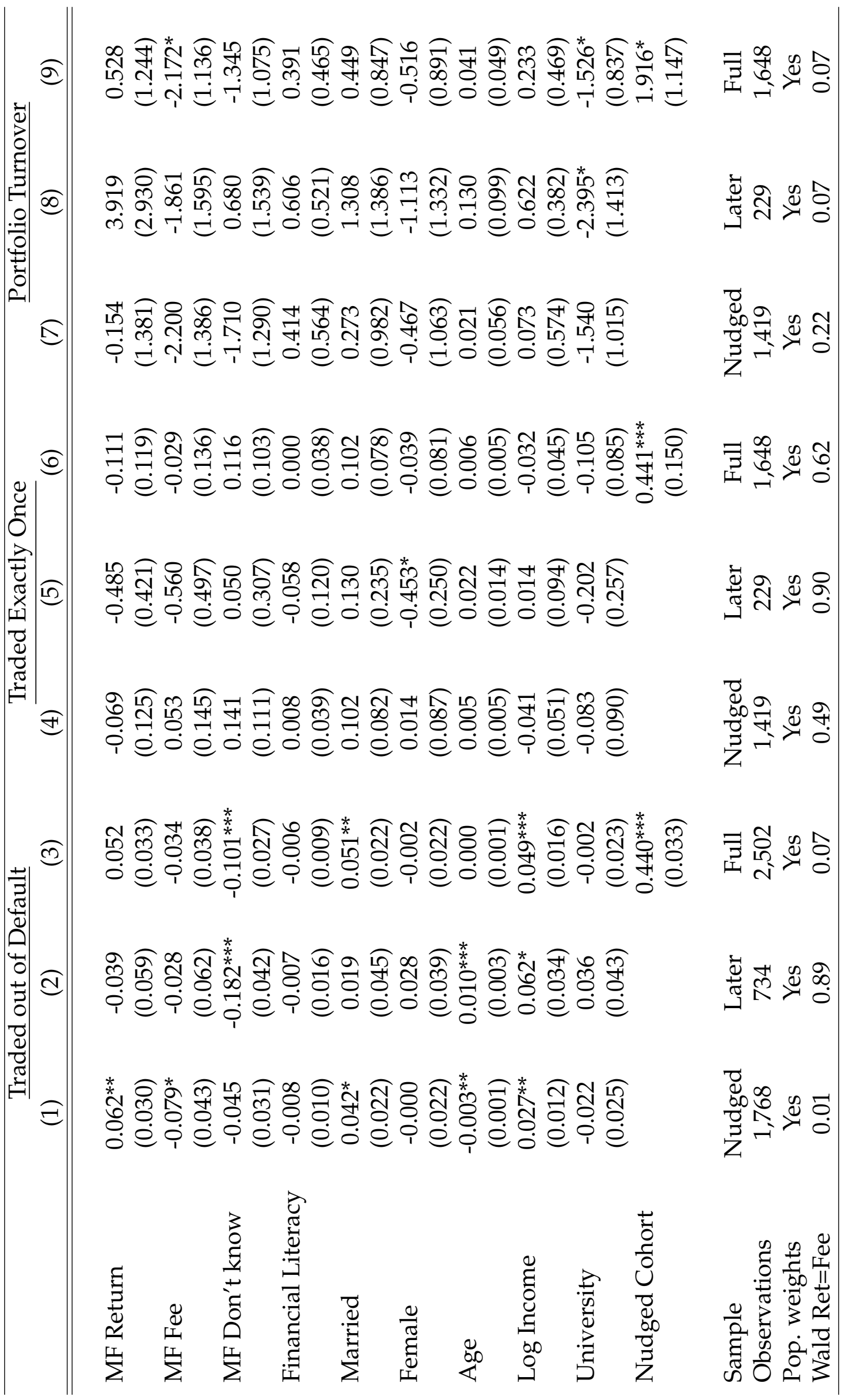




\section{Table VII: Working with mass-market advisors}

This table reports Probit regressions where the dependent variable that takes the value of one if classified as having used a mass-market advisor (MMA), zero otherwise. The full sample consists of 2,502 observations, the nudged sample refers to the 1,768 investors coming in during the year 2000, and the later sample consists of the remaining 734 later entrants. Columns (1) through (3) use a classification as being part of a collective rebalancing scheme of 1,000 coordinated changes ("Any"). Columns (4) through (6) repeats the analysis for trades at the 50th percentile ("MMA 50") of correlated changes, corresponding to 12,535 identical portfolio rebalances at a given day. The independent variables MF Return, MF Fee and MF DK takes the value of one if the respondent strongly agreed, strongly disagreed or reported don't know to the statement "When selecting a mutual fund, its past returns are more important than its fees"' and zero otherwise. Sampling weights based on the Swedish working-age population are applied to all specifications. Nudged Cohort is a dummy variable taking the value of one if the respondent was in the initial 2000 cohort, zero otherwise. Rejection probabilities from a Wald test for difference in coefficients between MF Return and MF Fee are included at the bottom of the table. Point estimates are reported as marginal probabilities. Intercepts are included but untabulated for brevity. Robust standard errors are reported in parentheses; one, two and three asterisks denote statistical significance at the 10, 5, and $1 \%$ level.

\begin{tabular}{|c|c|c|c|c|c|c|}
\hline & \multicolumn{3}{|c|}{ Any $(1,000$ trades $)$} & \multicolumn{3}{|c|}{$50^{t h}(12,000$ trades $)$} \\
\hline & (1) & $(2)$ & (3) & (4) & (5) & (6) \\
\hline \multirow[t]{2}{*}{ MF Return } & 0.023 & -0.001 & 0.012 & $0.057^{*}$ & 0.018 & $0.042^{* *}$ \\
\hline & $(0.033)$ & (0.019) & $(0.022)$ & $(0.030)$ & $(0.019)$ & $(0.020)$ \\
\hline \multirow[t]{2}{*}{ MF Fee } & -0.050 & 0.003 & -0.024 & $-0.047^{*}$ & 0.012 & -0.014 \\
\hline & $(0.034)$ & $(0.019)$ & $(0.023)$ & $(0.028)$ & $(0.016)$ & $(0.019)$ \\
\hline \multirow[t]{2}{*}{ MF Don't know } & -0.005 & -0.021 & -0.021 & 0.014 & -0.008 & -0.000 \\
\hline & $(0.029)$ & $(0.015)$ & $(0.018)$ & $(0.025)$ & $(0.009)$ & $(0.014)$ \\
\hline \multirow{2}{*}{ Financial Literacy } & -0.011 & 0.001 & -0.006 & $-0.016^{* *}$ & -0.000 & $-0.009 * *$ \\
\hline & $(0.010)$ & $(0.004)$ & $(0.006)$ & $(0.008)$ & $(0.002)$ & $(0.005)$ \\
\hline \multirow[t]{2}{*}{ Married } & 0.011 & 0.016 & 0.017 & -0.021 & 0.011 & -0.004 \\
\hline & $(0.021)$ & $(0.018)$ & $(0.015)$ & $(0.018)$ & $(0.011)$ & $(0.011)$ \\
\hline \multirow[t]{2}{*}{ Female } & -0.020 & 0.002 & -0.012 & -0.009 & 0.007 & -0.003 \\
\hline & $(0.022)$ & $(0.014)$ & $(0.015)$ & $(0.018)$ & $(0.007)$ & $(0.011)$ \\
\hline \multirow[t]{2}{*}{ Age } & -0.001 & $0.001^{* *}$ & 0.001 & 0.001 & $0.001^{*}$ & $0.001^{*}$ \\
\hline & $(0.001)$ & $(0.001)$ & $(0.001)$ & $(0.001)$ & $(0.000)$ & $(0.001)$ \\
\hline \multirow[t]{2}{*}{ Log Income } & -0.002 & $0.029 * * *$ & 0.009 & 0.000 & $0.012^{* *}$ & 0.006 \\
\hline & $(0.012)$ & $(0.009)$ & $(0.009)$ & $(0.006)$ & $(0.006)$ & $(0.004)$ \\
\hline \multirow[t]{2}{*}{ University } & $-0.045^{* *}$ & $-0.020^{*}$ & $-0.033^{* *}$ & $-0.031^{*}$ & -0.007 & $-0.019^{*}$ \\
\hline & $(0.021)$ & $(0.011)$ & $(0.014)$ & $(0.018)$ & $(0.006)$ & $(0.010)$ \\
\hline \multirow[t]{2}{*}{ Nudged Cohort } & & & $0.112^{* * *}$ & & & $0.072^{* * *}$ \\
\hline & & & $(0.021)$ & & & $(0.017)$ \\
\hline Sample & Nudged & Later & Full & Nudged & Later & Full \\
\hline Observations & 1,768 & 734 & 2,502 & 1,768 & 734 & 2,502 \\
\hline Pop. weights & Yes & Yes & Yes & Yes & Yes & Yes \\
\hline Wald Ret=Fee & 0.11 & 0.89 & 0.23 & 0.02 & 0.77 & 0.04 \\
\hline
\end{tabular}

Robust standard errors in parentheses ${ }^{* * *} \mathrm{p}<0.01,{ }^{* *} \mathrm{p}<0.05,{ }^{*} \mathrm{p}<0.1$ 


\section{Table VIII: Choosing advisor-affiliated funds}

This table reports weighted Probit regressions of a dummy variable that takes the value of one if the respondent invests in an advisor-affiliated fund of funds (as identified by the SPA). The independent variables labelled MMA takes the value one if the investor is classified as having used mass-market advice and zero otherwise. MF Return, MF Fee and MF DK takes the value of one if the respondent strongly agreed, strongly disagreed or reported don't know to the statement "When selecting a mutual fund, its past returns are more important than its fees", and zero otherwise. Nudged Cohort is a dummy variable taking the value of one if the respondent was in the initial 2000 cohort, zero otherwise. Column (2) and (3) redefines the classification as being part of a collective rebalancing scheme that belong to the 25th and 50th percentile of correlated changes, corresponding to 3,076 and 12,535 identical portfolio rebalances at a given day in a separate sample of 480,000 retirement accounts. Column (1) to (4) display the results for all respondents and Column (5) includes only investors who opted out of the default fund. Sampling weights based on the Swedish working-age population are applied to all specifications. Rejection probabilities from a Wald test for difference in coefficients between MF Return and MF Fee are included at the bottom of the table. Point estimates are reported as marginal probabilities. Intercepts are included but untabulated for brevity. Robust standard errors are reported in parentheses; one, two and three asterisks denote statistical significance at the 10,5 , and $1 \%$ level.

\begin{tabular}{|c|c|c|c|c|c|}
\hline VARIABLES & $\begin{array}{c}(1) \\
\text { A-fund }\end{array}$ & $\begin{array}{c}(2) \\
\text { A-fund }\end{array}$ & $\begin{array}{c}(3) \\
\text { A-fund }\end{array}$ & $\begin{array}{c}(4) \\
\text { A-fund }\end{array}$ & $\begin{array}{c}(5) \\
\text { A-fund }\end{array}$ \\
\hline MMA / All & & & & $\begin{array}{c}0.387^{* * *} \\
(0.031)\end{array}$ & \\
\hline MMA / 50th & & & & & $\begin{array}{c}0.417^{* * *} \\
(0.039)\end{array}$ \\
\hline Nudged 2000 & & & $\begin{array}{c}0.091^{* * *} \\
(0.021)\end{array}$ & $\begin{array}{l}0.047^{* *} \\
(0.020)\end{array}$ & $\begin{array}{c}0.064^{* * * *} \\
(0.021)\end{array}$ \\
\hline MF Return & $\begin{array}{c}0.107^{* * *} \\
(0.038)\end{array}$ & $\begin{array}{c}0.024 \\
(0.036)\end{array}$ & $\begin{array}{c}0.074^{* * *} \\
(0.028)\end{array}$ & $\begin{array}{c}0.070^{* * *} \\
(0.027)\end{array}$ & $\begin{array}{l}0.055^{* *} \\
(0.027)\end{array}$ \\
\hline MF Fee & $\begin{array}{l}-0.007 \\
(0.035)\end{array}$ & $\begin{array}{l}-0.026 \\
(0.023)\end{array}$ & $\begin{array}{l}-0.016 \\
(0.023)\end{array}$ & $\begin{array}{l}-0.004 \\
(0.024)\end{array}$ & $\begin{array}{l}-0.007 \\
(0.024)\end{array}$ \\
\hline MF Don't know & $\begin{array}{c}0.043 \\
(0.029)\end{array}$ & $\begin{array}{l}-0.004 \\
(0.022)\end{array}$ & $\begin{array}{c}0.019 \\
(0.020)\end{array}$ & $\begin{array}{c}0.024 \\
(0.019)\end{array}$ & $\begin{array}{c}0.015 \\
(0.019)\end{array}$ \\
\hline Financial Literacy & $\begin{array}{l}-0.015^{*} \\
(0.009)\end{array}$ & $\begin{array}{l}-0.005 \\
(0.007)\end{array}$ & $\begin{array}{l}-0.012^{*} \\
(0.006)\end{array}$ & $\begin{array}{l}-0.010 \\
(0.006)\end{array}$ & $\begin{array}{l}-0.008 \\
(0.006)\end{array}$ \\
\hline Married & $\begin{array}{l}-0.012 \\
(0.020)\end{array}$ & $\begin{array}{c}0.034 \\
(0.023)\end{array}$ & $\begin{array}{c}0.006 \\
(0.015)\end{array}$ & $\begin{array}{c}0.002 \\
(0.014)\end{array}$ & $\begin{array}{c}0.011 \\
(0.015)\end{array}$ \\
\hline Female & $\begin{array}{l}-0.022 \\
(0.021)\end{array}$ & $\begin{array}{c}0.007 \\
(0.017)\end{array}$ & $\begin{array}{c}-0.008 \\
(0.015)\end{array}$ & $\begin{array}{c}-0.003 \\
(0.014)\end{array}$ & $\begin{array}{l}-0.006 \\
(0.015)\end{array}$ \\
\hline Age & $\begin{array}{l}-0.001 \\
(0.001)\end{array}$ & $\begin{array}{c}0.000 \\
(0.001)\end{array}$ & $\begin{array}{c}0.000 \\
(0.001)\end{array}$ & $\begin{array}{l}-0.000 \\
(0.001)\end{array}$ & $\begin{array}{l}-0.001 \\
(0.001)\end{array}$ \\
\hline Log Income & $\begin{array}{c}0.000 \\
(0.009)\end{array}$ & $\begin{array}{l}0.026^{* * *} \\
(0.012)\end{array}$ & $\begin{array}{l}0.012^{*} \\
(0.007)\end{array}$ & $\begin{array}{c}0.008 \\
(0.006)\end{array}$ & $\begin{array}{c}0.012 \\
(0.008)\end{array}$ \\
\hline University & $\begin{array}{l}-0.002 \\
(0.023)\end{array}$ & $\begin{array}{l}-0.015 \\
(0.019)\end{array}$ & $\begin{array}{l}-0.008 \\
(0.017)\end{array}$ & $\begin{array}{c}0.007 \\
(0.017)\end{array}$ & $\begin{array}{c}0.002 \\
(0.017)\end{array}$ \\
\hline Observations & 1,768 & 734 & 2,502 & 2,502 & 2,502 \\
\hline Sample & Nudged & Later & Full & Full & Full \\
\hline Pop. weights & Yes & Yes & Yes & Yes & Yes \\
\hline MF Ret-MF Fee=0 & 0.02 & 0.20 & 0.01 & 0.03 & 0.06 \\
\hline
\end{tabular}




\section{Table IX: Fees}

This table reports weighted OLS regressions on mutual fund fees. The dependent variable is the weighted average fee percentage they face in their fund holdings, computed by weighting each fund's fee percentage by that fund's weight in their portfolio at the end of 2015. The independent variable MMA 50 takes the value one if the investor has participated in coordinated trades defined at the median, and zero otherwise. MF Return, MF Fee and MF DK takes the value of one if the respondent strongly agreed, strongly disagreed or reported don't know to the statement 'When selecting a mutual fund, its past returns are more important than its fees", and zero otherwise. Nudged Cohort is a dummy variable taking the value of one if the respondent was in the initial 2000 cohort, zero otherwise. Columns (2) through (5) include variables that measure the fraction of each respondent's fund invested in each of the four fund types: equity funds, bond funds, target-date funds, and money market funds. Columns (1) through (4) include only those respondents who opted out of the default fund, while Column (5) includes the full sample. Sampling weights based on the Swedish working-age population are applied to all specifications. Investor characteristics controls correspond to those in Table VIII. Rejection probabilities from a Wald test for difference in coefficients between MF Return and MF Fee are included at the bottom of the table. Intercepts are included but untabulated for brevity. Robust standard errors are reported in parentheses; one, two and three asterisks denote statistical significance at the 10,5 , and $1 \%$ level.

\begin{tabular}{|c|c|c|c|c|c|}
\hline & (1) & (2) & (3) & (4) & (5) \\
\hline VARIABLES & Fee & Fee & Fee & Fee & Fee \\
\hline MMA / 50th & $\begin{array}{c}0.076^{* * *} \\
(0.014)\end{array}$ & $\begin{array}{c}0.061^{* * *} \\
(0.009)\end{array}$ & & $\begin{array}{c}0.059^{* * * *} \\
(0.009)\end{array}$ & $\begin{array}{c}0.085^{* * *} \\
(0.011)\end{array}$ \\
\hline MF Return & & & $\begin{array}{l}0.021^{* *} \\
(0.011)\end{array}$ & $\begin{array}{l}0.018^{*} \\
(0.010)\end{array}$ & $\begin{array}{l}0.018^{*} \\
(0.010)\end{array}$ \\
\hline MF Fee & & & $\begin{array}{l}-0.013 \\
(0.015)\end{array}$ & $\begin{array}{l}-0.009 \\
(0.014)\end{array}$ & $\begin{array}{l}-0.007 \\
(0.011)\end{array}$ \\
\hline MF Don't know & & & $\begin{array}{l}-0.005 \\
(0.009)\end{array}$ & $\begin{array}{l}-0.005 \\
(0.008)\end{array}$ & $\begin{array}{c}-0.032^{* * *} \\
(0.007)\end{array}$ \\
\hline Financial Literacy & $\begin{array}{c}0.003 \\
(0.004)\end{array}$ & $\begin{array}{c}-0.002 \\
(0.004)\end{array}$ & $\begin{array}{l}-0.003 \\
(0.004)\end{array}$ & $\begin{array}{l}-0.003 \\
(0.004)\end{array}$ & $\begin{array}{l}-0.001 \\
(0.003)\end{array}$ \\
\hline Nudged Cohort & $\begin{array}{l}-0.011 \\
(0.018)\end{array}$ & $\begin{array}{l}-0.020 \\
(0.014)\end{array}$ & $\begin{array}{l}-0.017 \\
(0.014)\end{array}$ & $\begin{array}{l}-0.021 \\
(0.014)\end{array}$ & $\begin{array}{c}0.070^{* * *} \\
(0.010)\end{array}$ \\
\hline Constant & $\begin{array}{c}0.308^{* * * *} \\
(0.082)\end{array}$ & & & & \\
\hline Observations & 1,648 & 1,648 & 1,648 & 1,648 & 2,502 \\
\hline R-squared & 0.029 & 0.863 & 0.860 & 0.864 & 0.771 \\
\hline Demographics & Yes & Yes & Yes & Yes & Yes \\
\hline Population weights & Yes & Yes & Yes & Yes & Yes \\
\hline Strategy weights & No & Yes & Yes & Yes & Yes \\
\hline Wald Ret=Fee & - & - & 0.04 & 0.09 & 0.08 \\
\hline
\end{tabular}




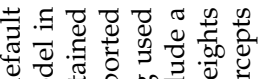

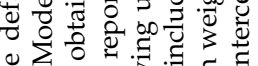

t.

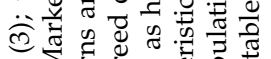

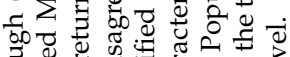

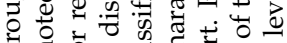

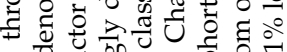

-

Hent

WII

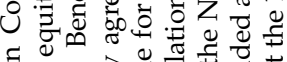

(1)

I

W.

(n)

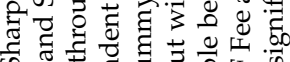

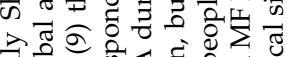

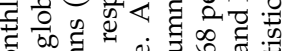

Wy

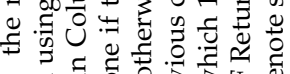

En

పี

ह્વ

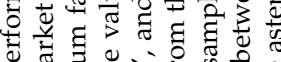

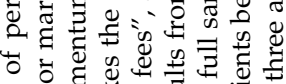

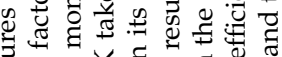

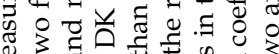

巳 引

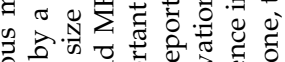

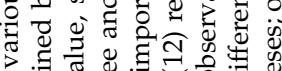

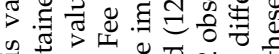

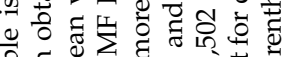

然

Whet

浣

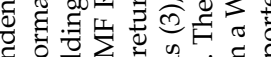

ट

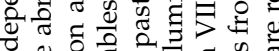

Q

‡过

ป 웡

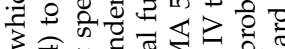

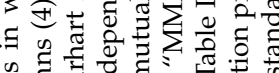

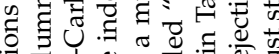

क స

ڤั

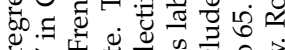

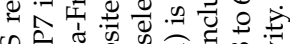

थ

on:

stom

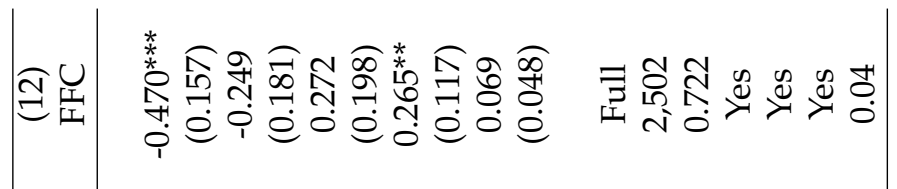

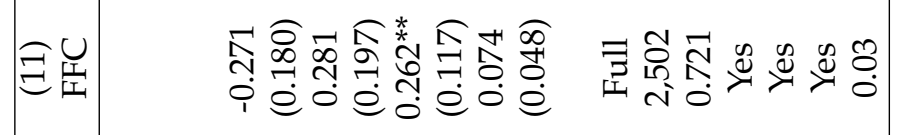

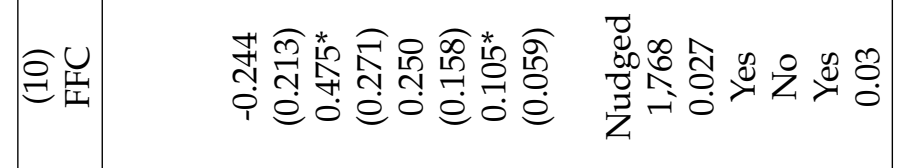

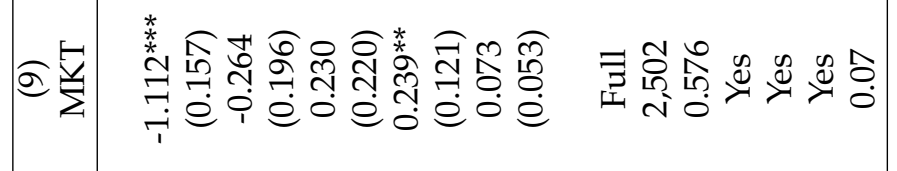

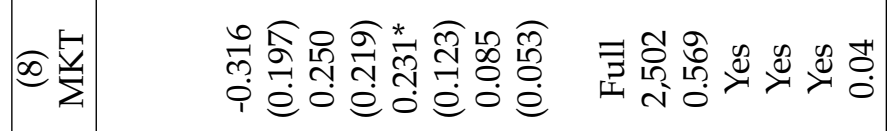

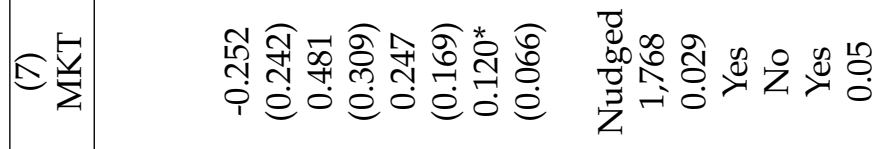

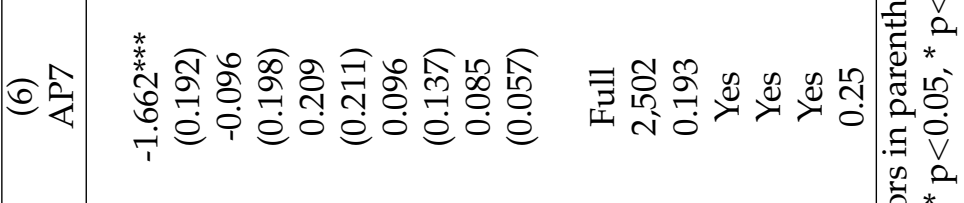

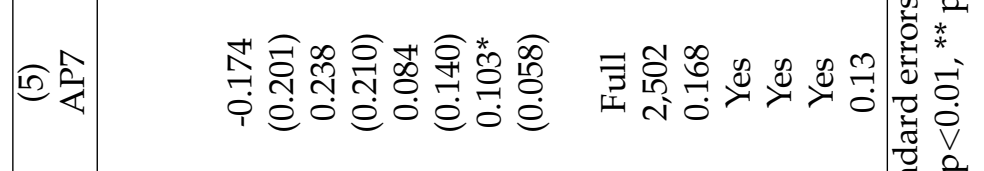

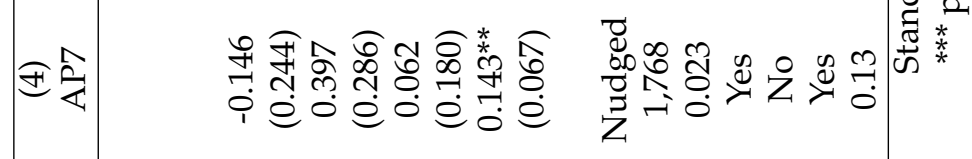

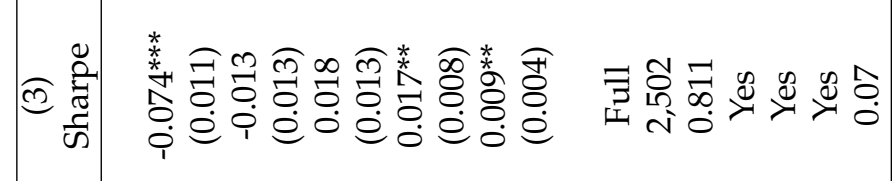

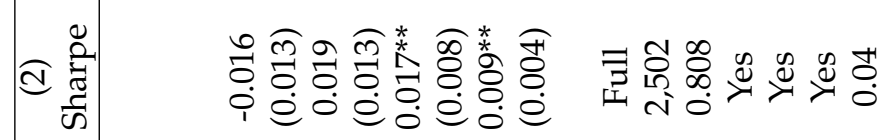

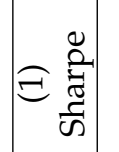

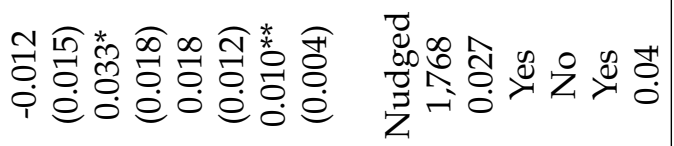

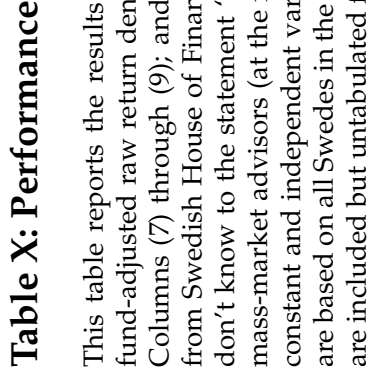

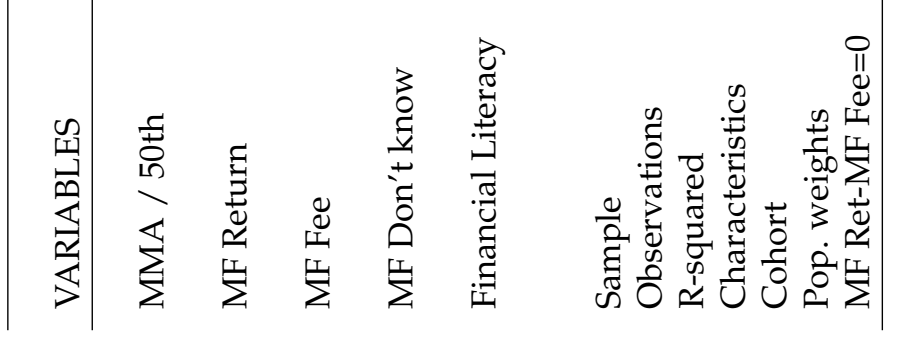




\section{Figure 1: Beliefs about fees vs. past returns across financial literacy scores}

This figure shows the number of respondents sorted on financial literacy score ("Actual Score"; bars, right scale), together with mean self-estimated correct score, labelled Perceived Score, traced by the solid line (left scale). The dotted 45-degree line indicates a perfect match between Actual and Perceived Score. The bars show the proportion respondents strongly agreeing or disagreeing to the statement "When selecting a mutual fund, its past returns are more important than its fees."

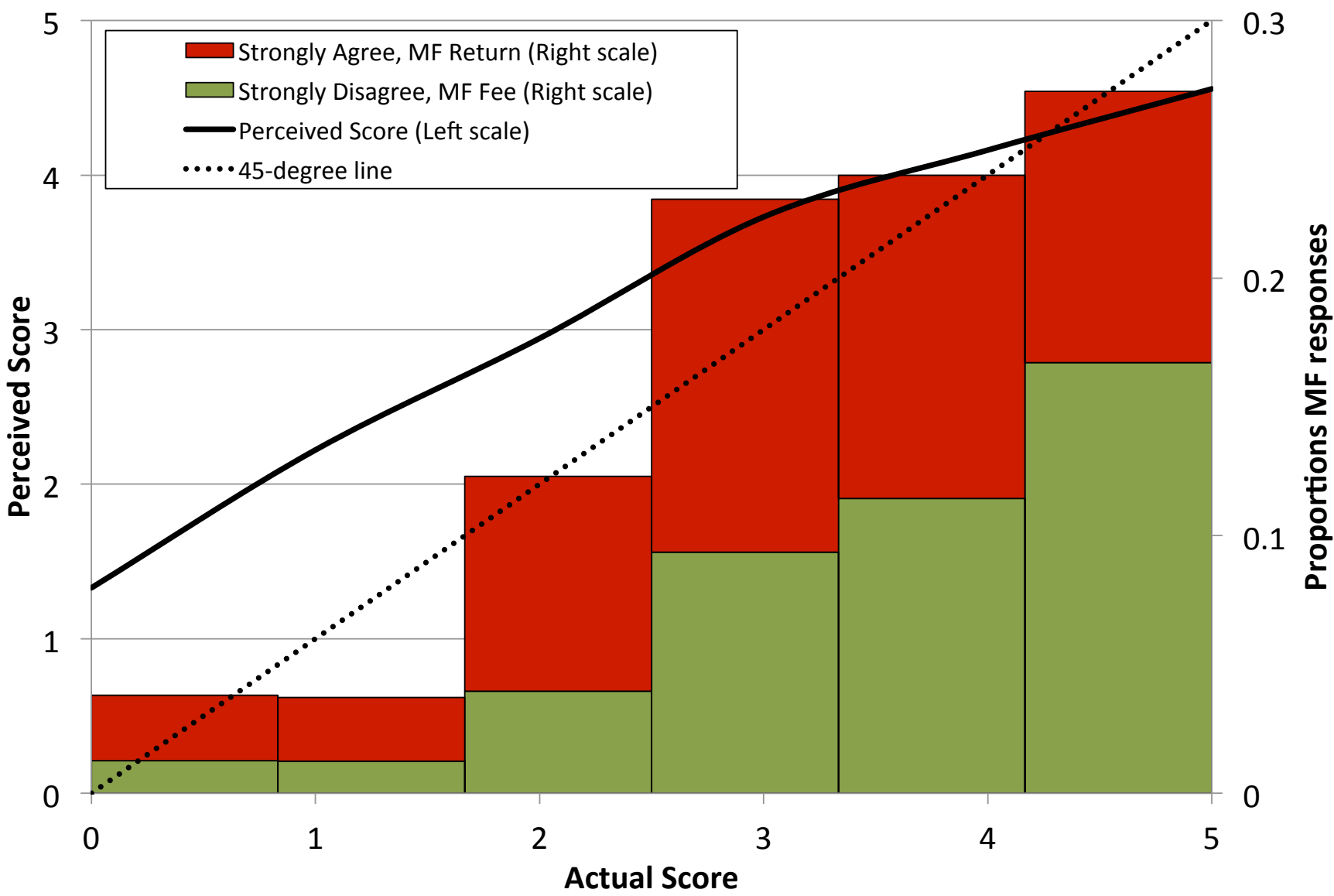




\section{Figure 2: Distribution of market model alphas}

This graph displays the distribution of the $\alpha_{i}$ from the regression of each respondent's portfolio excess return on two market excess returns, $R_{i t}-r_{f t}=\alpha_{i}+\beta_{S, i} R_{S, t}+\beta_{G, i} R_{G, t}+\epsilon_{i t}$, where $S$ and $G$ denote the Swedish excess market return and the Global excess market return, respectively. The dark-shaded portion of the graph correspond to $\alpha_{i}<0$. The OLS-regression is estimated using monthly data from 2000 to 2015 on a sample of 1,678 respondents that were not in the default fund at the end of 2015.

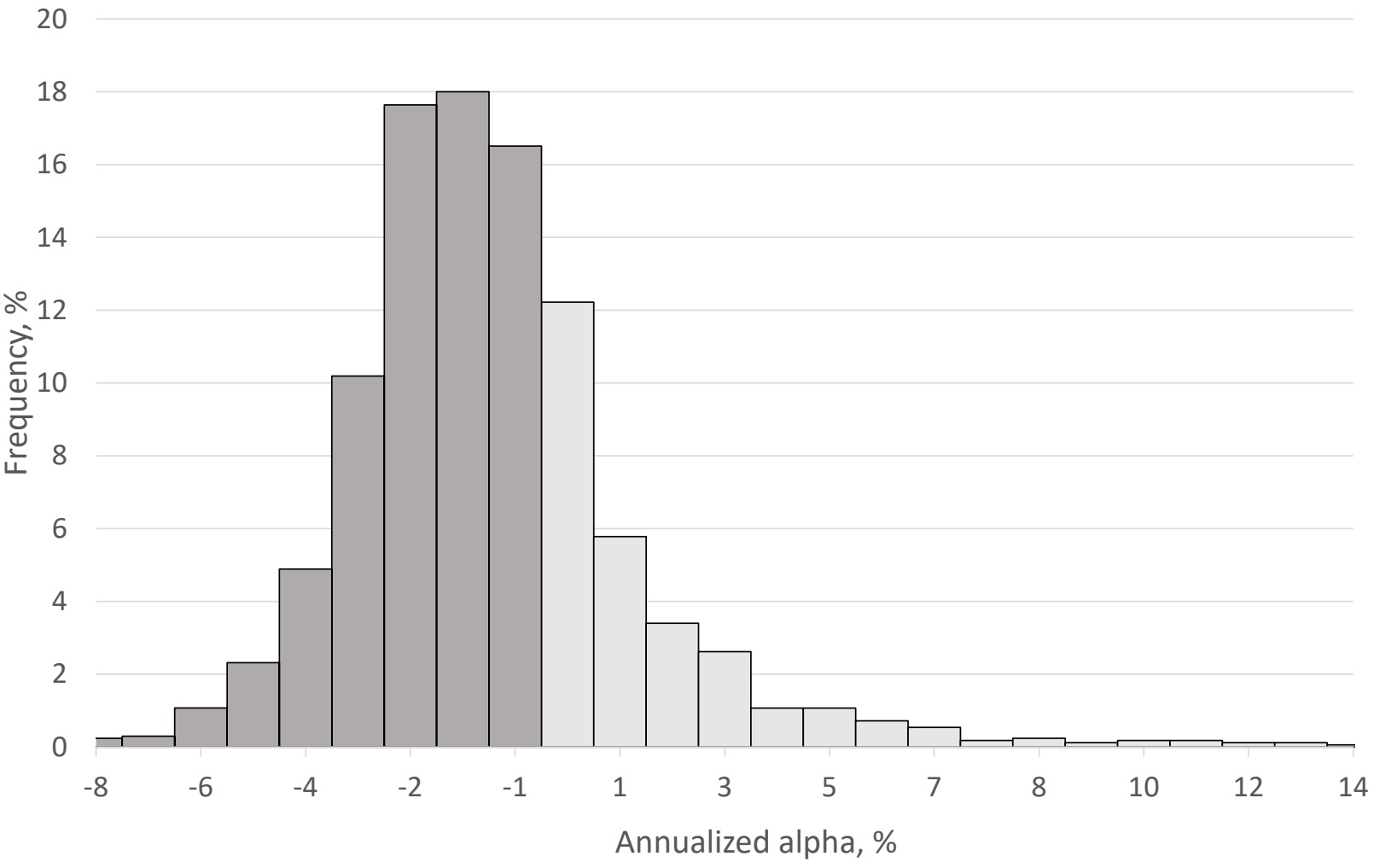




\section{A Online Appendix}

This Appendix contains the distribution of answers to the questions in our financial literacy survey and a plot of the belief distribution across scores of the financial literacy test. 


\section{Table A.1: Five Modified Financial Literacy Questions}

Below are the five ("Big 5") financial literacy questions used in the study and corresponding frequency responses on each item. Correct answers are highlighted in boldface. The questions have been translated from Swedish into English.

1. Compounding. Suppose you had $\$ 100$ in a savings account and the interest rate was $2 \%$ per year. After 5 years, how much do you think you would have in the account if you left the money to grow? Please select one.

- More than $\$ 102(92 \%)$

- Exactly $\$ 102(2 \%)$

- Less than $\$ 102(3 \%)$

- Don't know (2\%)

- Prefer not to say $(1 \%)$

2. Inflation. Imagine that the interest rate on your savings account was $1 \%$ per year and inflation was $2 \%$ per year. After 1 year, how much would you be able to buy with the money in this account? Please select one.

- More than today $(6 \%)$

- Less than today $(81 \%)$

- Exactly the same as today 3\%)

- Don't know (8\%)

- Prefer not to say $(2 \%)$

3. Diversification. Buying a single company's stock usually provides a safer return than a stock mutual fund. Please select one.

- True $(4 \%)$

- False (76\%)

- Don't know (19\%)

- Prefer not to say $(1 \%)$

4. Saving. Suppose you were given 10,000 as a gift and wanted to double the amount by saving the money ten years without having to touch it. What interest rate would you require to achieve this goal? Please select one.

- About $15 \%$ annual interest rate $(6 \%)$

- About $10 \%$ annual interest rate $(45 \%)$

- About $7 \%$ annual interest rate $(43 \%)$

- Don't know (5\%)

- Prefer not to say $(1 \%)$

5. Bond Pricing. If interest rates fall, what should happen to bond prices? Please select one.

- They will rise $(23 \%)$

- They will fall (17\%)

- They will stay the same (45\%)

- Don't know (14\%)

- Prefer not to say $(1 \%)$ 
Table A.2: Question about beliefs and household planning

Below are the questions and responses for the mutual fund belief and household planning questions reported in Table IV. Dummy variables taking the value of one for each response highlighted in boldface. The questions have been translated from Swedish into English.

1. Past returns and fees. Do you agree or disagree with the following statement when choosing a mutual fund:"When selecting an equity mutual fund, its past returns are more important than its fees" Please select one.

- Strongly agree (11\%), labelled "MF Return"

- Agree (34\%)

- Disagree (19\%)

- Strongly disagree (9\%), labelled "MF Fee"

- Don't know (25\%), labelled “MF DK"

- Prefer not to say $(2 \%)$

2. Retire. Have you ever tried to figure out how much to save for retirement? Please select one.

- Yes $(48 \%)$

- No $(49 \%)$

- Don't know (1\%)

- Prefer not to say $(2 \%)$

3. Advice. Would you be willing to accept free financial advice it was offered to you? Please select one.

- Yes $(36 \%)$

- No $(24 \%)$

- Maybe, it depends (37\%)

- Don't know (2\%)

- Prefer not to say $(2 \%)$

4. Finance interesting. Do you agree or disagree with the following statement? "I think personal financial matters are boring." Please select one.

- Agree (12\%)

- Agree somewhat (39\%)

- Disagree (22\%)

- Strongly disagree (25\%)

- Don't know (1\%)

- Prefer not to say $(1 \%)$

5. Decision maker. Who is primarily respsonsible for planning the savings decisions in your household? Please select one.

- Myself (50\%)

- Someone else $(6 \%)$

- I share respsonsiblitiy (40\%)

- Financial advisor (1\%)

- Someone else in the family or friend $(0 \%)$

- I don't save (1\%)

- I don't plan (1\%)

- Prefer not to say $(1 \%)$ 


\section{Figure A.3: Beliefs about financial literacy scores}

This figure shows the average beliefs distribution of self-assessed scores ("Perceived Score", bottom scale) across actual financial literacy score ("Actual Score", right scale). There are 2,502 respondents in sample. The average of the belief distribution is used to compute the variable "Perceived Score" in the main text.

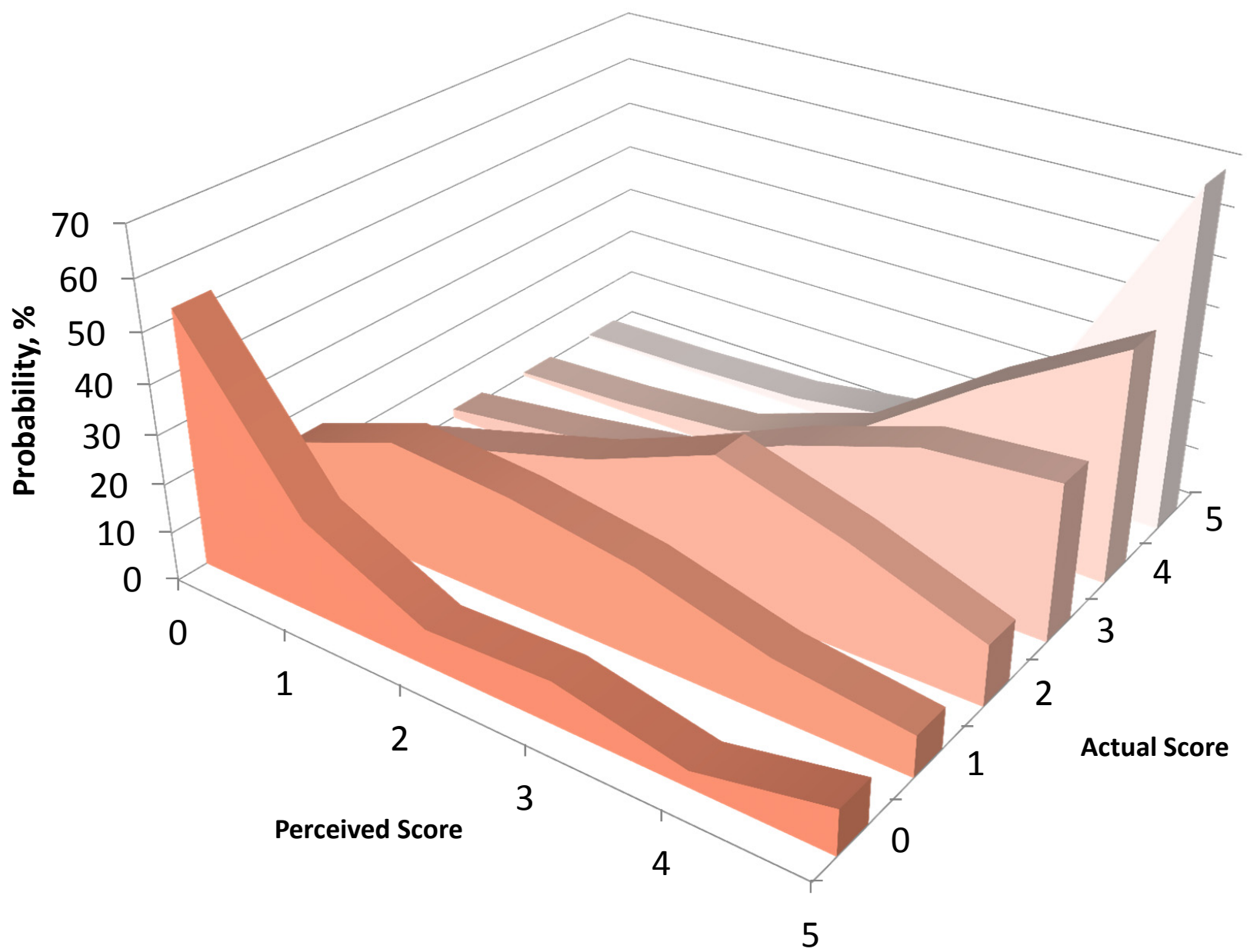

